\title{
EtIología Jíbara l: ORIGEN DE LA MONOGAMIA, EL ZAPALLO, LA ARCILLA Y LAS MANCHAS DE LA LUNA
} Enrique Ballón Aguirre

En este primero de dos artículos,el autor pone en tela de juicio la semisimbolización establecida por C.Lévi-Strauss entre la alfarera y los celos a partir de un corpus de variantes míticas tomadas a la etnia Jíbara. Reproduciendo los textos completos de los resúmenes utilizados por el antropólogo francés, y de otras variantes más que amplian el corpus original por medio del análisis semio-lingüístico del discurso etnoliterario, se logra demostrar el desplazamiento nocional de un motivo a otro que sufre dicho estudio,todo con el fin de precisar la interpretación semántica de los textos. El artículo complementario estará dedicado a examinar las versiones correspondientes al origen de la actividad alfarera entre los Jíbaros, discutiéndose entonces los alcances de los acercamientos antropológico y semiótico en la determinación del sentido cuando se trata de conocer la etnoliteratura alejada de la cosmovisión occidental.

In this first of two article, the author questions the semi-symbolization established by C. Lévi-Strauss linking the pottery maker and jealousy, based on a corpus of mythic versions taken from the Jivaro ethnic group. Using the complete texts of material that the French anthropologist abridged and others versions that more than amplify the original corpus, Ballón, using a semio-linguistic analysis of the ethno-literary discourse, demonstrates the notional displacement of one theme to another that thestudy undergoes in order to define the semantic interpretation of the texts. A complementary article will be devoted to an examination of the versions corresponding to the pottery making activity among the Jivaros, discussing the significance of an anthropological and semiotic approach in the determination of meaning when it involves ethnoliterature far removed from the western cosmovision. 
Nuestras categorias no debieran ser más que un punto de partida destinado a ser dejado de lado. Los conceptos que usamos deben cambiar constantemente porque en antropología no se trata de confirmar la validez de categorías sino de comprender a pueblos que nos son extraños.

Lévi-Strauss, C., 1991: 282.

Todo antropólogo atento al relativismo cultural no puede ignorar que la idea que nos hacemos de lo que es una "pasión" varía de un lugar a otro, de una época a otra y que la articulación del universo pasional define incluso, hasta cierto punto, las especificidades culturales.

Greimas, A. J. y Fontanille, J., 1991: 17.

\section{LA ETIOLOGÍA ETNOLITERARIA}

Hasta hace relativamente poco, al hablar de la producción del lenguaje era muy común en la lingüística frasal oponer la visión diacrónica o evolutiva, a través del tiempo, a su visión sistemática en un momento dado o sincronía. Sin embargo, hoy prima una perspectiva más bien integradora a la luz de los fenómenos de discurso y enunciación: los diversos estados de cada sistema en una lengua dada, sólo pueden describirse y explicarse por la transformación de unos en otros, es decir que la sincronía encuentra su razón de ser gracias a la diacronía y a la inversa.

Este modo de ver las cosas no sólo es más adecuado para el examen de la práctica de la lengua dentro de los grupos sociales concernidos, sino que permite tender puentes interdisciplinarios desde la lingüística del discurso hacia la antropología y la historia ${ }^{(1)}$. Hacia la primera, ya que, por ejemplo, un determinado relato etnoliterario se constituye como texto único (en sincronía), gracias a la serie de correlaciones que puede establecerse entre todas sus variantes conocidas en el tiempo (en diacronía); y hacia la segunda, ya que la llamada dialéctica de la duración histórica presenta las duraciones cortas (mutatis mutandis,sincrónicas) insertas en las duraciones largas (o diacrónicas). Pero además, las praxis histórica, antropológica y lingüística, se desarrollan con un ritmo lento en el caso de las sociedades ancestrales y rápido en las industriales, es decir que la duración histórica afecta a la producción cultural de cada grupo social, especialmente si se trata de sociedades multilingües y pluriculturales 
como la nuestra en la que conviven diversas sociedades ancestrales y una predominante de proveniencia occidental ("criolla"), cada una con su ritmo histórico y cultural propio.

$\mathrm{Si}$, por ejemplo, se observa el fenómeno de lengua a nivel global en toda la sociedad peruana, constatamos que allí se produce la amalgama heteroglósica de las lenguas (especialmente entre el quechua y el aimara y entre ambas lenguas y el castellano) en todos los planos de la descripción lingüística, desde el fonético hasta el semántico, tanto en su duración larga -con la subsistencia de relictos gramaticales- como en las duraciones cortas donde se explican los fenómenos transitorios, igualmente gramaticales, y que nos dejan huella permanente. Tal es el caso, más preciso, de la diglosia léxica donde se generan -por préstamos y calcos mutuos- los peruanismos relativamente perdurables, pero también y al mismo tiempo, en las duraciones cortas aparecen los fenómenos producto del cambio léxico incesante tales como la jerga escolar y universitaria, el habla del hampa y nuestros diversos argots.

Tomando ahora los fenómenos discursivos producidos en esta misma sociedad, se plantea de inmediato la situación de las distintas "velocidades" ( $e l$ tempo) de la actividad enunciativa general. Si nos circunscribimos más aún a la enunciación de los discursos literarios, en los etnoliterarios (intraculturales) y de literatura oral (interculturales), ambos colectivos por definición, las "velocidades" cortas (o mejor, rápidas) aparecen en cada variante (texto cerrado) de un relato y las largas y más o menos sólidas (o lentas) se dan en el conjunto de variantes conocidas -temporal y espacialmente- de ese mismo relato (texto abierto) ${ }^{2}$; en cambio, en la literatura escrita, individual por definición, encontramos la "velocidad" rápida con cada versión de una misma obra - poesía, prosa, ensayo, pieza de teatro, etc.- y la lenta con la estabilización del "texto definitivo"3. Por último, si nos colocamos en la perspectiva de la historia de la literatura, las distintas reediciones y la lectura por varias generaciones de una misma obra conforman la "velocidad" lenta, parsimoniosa, y con ello el corpus refrigerado de nuestra literatura "clásica", "imperecedera" desde Garcilaso hasta Vallejo; la "velocidad" rápida se encuentra claramente inscrita en la aparición y pronta desaparición "por siempre jamás" de las obras perecibles y abandonadas a la intemperie, al vaivén de los estilos, las escuelas, los períodos, los géneros: son, desde luego, las obras literarias que una vez escritas y publicadas, tienen una receptividad nula o muy pequeña. Ellas desaparecen de las antologías, son consignadas marginalmente en las historias de la literatura o simplemente se dejan al cuidado del afán erudito. 
Por eso, para las disciplinas sociales aludidas, un discurso-ocurrencia resulta siempre del cruce diacrónico-sincrónico equivalente al encuentro entre la evolución y el sistema de la lengua. Esto es lo que se constata siempre, repito, frente a los relatos orales y etnoliterarios donde nunca se puede registrar el texto definitivo; lo único que puede conseguirse es una variante a ser colacionada con otras variantes anteriores, concomitantes y posteriores -sociolectales para los primeros y etnolectales para los segundos-del mismo grupo. Perosi bien desde el enfoque de la enunciación cada variante tomada por sí sola es una macroconfiguración en acto (un relato oral incluye, por los general, más de un programa narrativo), ella es también, desde el punto de vista de la "larga duración" enunciativa, un objeto de lengua duro, un texto durable, donde se fijan los esquemas relativos a las áreas y a las épocas culturales. De ahí que un relato de este orden, diacrónica y sincrónicamente dispuesto, sea un objeto empírico único que se ofrece, en cuanto tal, a diversos objetos de conocimiento como la lingüística del discurso (o del texto), el folklore, los estudios literarios, la antropología, la semiótica, la historia...

Así, en cuanto macro-configuración, el relato oral en su respectiva variante reúne y comprende distintas configuraciones que articulan, cada una por separado, figuras y temas de muy diverso tipo. El proyecto que me ocupa aquí tratará de describir y explicar algunas variantes y sus motivos, variantes que siendo en principio subjetivas (idiolectales, pues cada una constituye un todo narrativo emitido por un informante) y por lo tanto pertenecientes a la corta duración; sin embargo son reconocidas como partes integrantes de formas culturales más o menos fijadas (etnolectales, ya que pertenecen al patrimonio, a la logósfera de una etnia), de larga duración. Me refiero a las variantes que contienen configuraciones propias de la etiología (=explicación de la causa u origen de las cosas) en un corpus tomado de una sola área cultural, las mismas que son dispuestas en los relatos etnoliterarios de ese corpus elegido para usos sean conformes sean desviantes respecto de sus manifestaciones canónicas o típicas (arquetípicas, prototípicas y estereotípicas) en este género de relatos.

\section{DE LA HIPÓTESIS A LA DEMOSTRACIÓN ANTROPOLÓGICA}

Vistas las cosas de ese modo, aparece sin dudas un nuevo punto de contacto sincrónico-diacrónico, esta vez entre la semiótica y la lingüística del discurso, de un lado, y la antropología del otro. En efecto, las clases dictadas por Claude Lévi-Strauss en el Colegio de Francia durante el año lectivo 1964-1965, 
tuvieron como tema general lo que él llamó "bocetos para un vestiario americano"4 . En efecto, allí Lévi-Strauss trató de definir, en primer lugar, "el emplazamiento que ocupa, en los mitos sudamericanos, un animal de las regiones tropicales del Nuevo Mundo: el perezoso" como potencia cósmica con ciertas cualidades particulares de defecación y un pueblo ctónico de enanos sin ano "obligados a alimentarse de humo", pero relacionados homológicamente "con una pequeña fauna arborícola" como los perezosos, las ardillas, los monos, etc., ya que "las creencias relativas a los enanos ctónicos parecían resultar de la necesidad lógicamente sentida, de un término cuya posición frente a los humanos fuera la misma quela de los humanos frentea los animales arborícolas"; en segundo lugar, "había que averiguar si esta fauna arborícola estaba ella misma articulada por los mitos para formar un sistema de significaciones y si, en ese sistema, el personaje del perezoso conservaba todos sus rasgos pertinentes". Poniendo en juego numerosas variantes de mitos tomados de distintos etnolectos dispares en el tiempo y el espacio (de Sudamérica: Tacana de Bolivia, Kalina de la Guyana holandesa, Mundurucu, Waiwai, Baré, Ipurina, etc. y de Norteamérica), pero especialmente "gracias a la mitología de los jíbaros del oriente peruano donde el perezoso tiene un rol incomparable", logra establecer un sistema triangular de correspondencias entre ciertos "símbolos zoológicos"5 que se diagramaría del siguiente modo:

chotacabras

(Caprimúlgido)

/avidez oral/

/ventosidad/

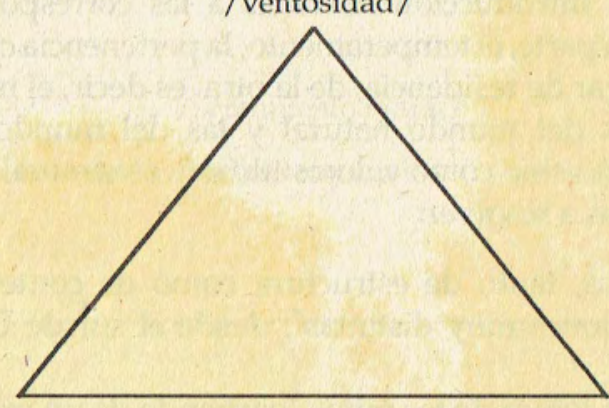

Perezoso

mono aullador

(Bradypus)

/retención oral/

(Alouatta)

/retención anal/

/incontinencia oral/

/incontinencia anal/ 
En este campo semántico triangular he conservado los géneros y familias correspondientes a cada animal, además de las connotaciones semánticas finales de la investigación, donde se advierte que "hay otros animales que se sitúan en los lados del triángulo, a distancias variables de los tres primeros. Otros aun, que también hemos encontrado, se sitúan en el interior del triángulo según su grado de proximidad o de distancia semántica con los tres animales que, desde sus posiciones estratégicas, dominan la totalidad del campo"6 y se subraya el "valor tópico" especial entre los mamíferos perezoso y mono aullador y el pájaro chotacabras por medio de la correlación y la oposición cuyos términos respectivos son carácter anal / carácteroral, lo cual conduceal antropólogo a elaborar conclusiones tanto de filosofía moral ("ciertos usos inmoderados del tubo digestivo - positiva o negativamente, por lo alto o por lo bajo-coincidentes, en cuanto a su área de distribución, con la de la cerbatana") como de psicología y psicoanálisis.

Ahora bien, en 1985, esto es, veinte años después, Lévi-Strauss publicó su obra La alfarera celosa ${ }^{7}$, libro donde, siguiendo los mismos principios de conocimiento desarrollados en esas clases -que aquí operan a manera de hipótesis-, se amplía enormemente la información inicial y los alcances de la demostración final realizada en esos cuatro lustros, convirtiéndose así en un modelo de investigación antropológica. En sus catorce capítulos, se procede a demostrar las hipótesis iniciales y al mismo tiempo a ampliar la información que ahora excede en mucho la propuesta original. En numerosas ocasiones el autor se detiene para reflexionar sobre el avance de la investigación que realiza, extendiendo su alcance a la función que cumplen los mitos en la humanidad y su potencia narrativa. Son especialmente importantes, a este respecto, las ideas desarrolladas en la introducción referidas a las correspondencias entre el aspecto físico de una parte, el temperamento, la pertenencia clánica, la supuesta procedencia o el lugar de residencia, de la otra, es decir, el mutuo reflejo entre las particularidades del mundo natural y las del mundo social, no como propiedades objetivas sino como valores filosóficos y morales; y la exposición de los tres problemas a resolver:

a) "señalar analogías, tanto de estructura como de contenido, entre mitos procedentes de regiones muy distintas", desde el sur de California hasta el Chaco;

b) en el campo de la lógica de los mitos "partiendo de un mito bien localizado y que, a simple vista, parece reconciliar términos desde todos los puntos de vista heteróclitos", seguirá "paso a paso las observaciones, las inferencias empíricas, los juicios analíticos y sintéticos, los razonamientos explícitos e implícitos que dan cuenta de su relación" y 
c) la distancia entre el pensamiento mítico y el análisis estructural del psicoanálisis.

En efecto, el estudio comienza con las tradiciones míticas de los jíbaros establecidos en la amazonía ecuatoriano-peruana. Lévi-Strauss resumeentonces las variantes recogidas por R. Karsten y J. M. Guallart de lo que él mismo considera "mito capital"; a ellas añade menciones a otros episodios de los relatos tomados por Ph. Descola (achuar; machiguengas), M. Stirling (jíbaros), S. Pellizzaro (shuar). A partir de ahí constata que esas variantes "prentenden explicar el origen ya sea del barro de alfarería, ya sea de las calabazas cultivadas, ya sea de las lianas del bosque" que relaciona gracias a las homologías:

"calabazas" - "lianas" :: / rastrera/-/trepadora/

"lianas"-"barro de alfarería"-"excrementos":: /informe/

"lianas":"arcilla" :: /masa desorganizada/: / masa moldeable/

"liana o cuerda":"bambú":: /informe/-/continuo/-/flexible/:/bien formado/ -/discontinuo/-/duro/

"bambú":"poste":: /nudoso/:/liso/

Seechará de ver fácilmente que los rasgos categoriales homologadores no son uniformes, pues obedecen a distintos grados de abstracción. Sin embargo, de todo ello se deduce la constante, en los mitos, de las figuras "calabazas", "lianas" y "barro de alfarería" y se recuerda la relación planteada ya por Karsten de la equivalencia entre la mujer y la alfarería. El enigma a dilucidar será, pues, tanto una relación transitiva (que representaré: $\rightarrow$ ) como una "deducción trascendental" (a representar: $\longleftrightarrow$ ) según el esquema:

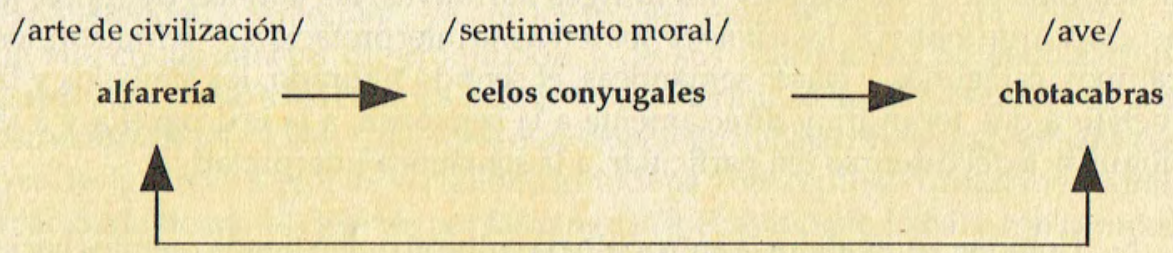

La conexión alfarería-celos se extiende a la cosmología norte y centroamericana (oglala dakotas, penobscot, hidatsas, menominis, siux, pueblo, jicaques) en que la mujer es agente o paciente de una conducta de celos, ampliándose las remisiones a la etnoliteratura tukuna, yagua y nuevamente 
jibara, para concluir que "esta conexión entre alfarería y celos es uno de los elementos básicos del pensamiento amerindio". A partir de esa constatación, se describirán los contenidos de innumerables textos míticos que el autor resume y en los cuales participan además de varios sistemas simbólicos otros zoemas importantes (un "micropanteón" zoológico: serpiente, diversos pájaros, rana, oso hormiguero, ardilla, cuchumbé, coendú, zarigüeya, mono, ratón, murciélago, tapir) entre los que ciertamente destacan, siguiendo la pauta inicialmente planteada, el chotacabras, el perezoso y el mono aullador, además de ingentes datos botánicos, cosmológicos (luna, sol, cometas, meteoros, aerolitos, los llamados tres universos - el de la fauna arborícola, el de la sociedad humana y el pueblo de los enanos-que explican homológicamente los pisos cósmicos "en una y otra parte del piso empírico" donde "en el mundo de arriba, una humanidad gigante esté en relación con los humanos como los humanos están en relación con los enanos y que en el mundo de abajo, una fauna arborícola gigante, ella también idealmente necesaria, esté en relación con los humanos como éstos en relación con la fauna arborícola real"), somáticos (orificios, digestión, cuerpo troceado, geofagia, excreciones, excrementos), de costumbres (en especial sobre canibalismo, decapitación y reducción de cabezas), rituales, la culinaria, la agricultura, las técnicas en las grandes artes de civilización que son la alfarería y el tejido, y por último, ciertos objetos usuales en las comunidades ancestrales americanas, especialmente la cerbatana, la pipa y otros tubos o cañas como la flauta.

Son particularmente interesantes, a mi entender, los comentarios de los dos últimos capítulos sobre los fenómenos de significación paradigmática y sintagmáticamente considerados, como la elección de los códigos semánticos ${ }^{8}$ de los mitos y su traducción en otros códigos, las denominadas tablas de desciframiento y sus casillas, las intrigas narrativas, las familias de mitos, la asociación de motivos, los leitmotiv, los temas, la interpretación, la definición, los campos, categorías y clases semánticas, el sentido figurado, los símbolos y la metáfora que tocan muy directamente a la semiótica, a la lexicografía y a la lingüística del discurso (en particular, a la semántica interpretativa).

Como se ve, es ahora la antropología cultural quien tiende puentes hacia estas últimas disciplinas. En efecto, para todas ellas el conjunto de las variantesocurrencias conocidas de un relato etnoliterario, conforman el tex to etnoliterario codificado pero siempre provisional, jamás acabado. ¿Qué es, pues, lo que constituye su unidad textual, qué lo hace ser un texto cerrado a pesar de estar inacabado? Desde la posición hipotético-deductiva del racionalismo empírico que defienden la lingüística del discurso y la semiótica, la respuesta está en el 
hecho de que todas las variantes son manifestaciones discursivas de un único y mismo contenido actualizado enunciativamente en una determinada forma por ejemplo, en un motivo o en una configuración específica-condensada o expandida por medio déuna serie isotópica codificada y no sólo virtualizada en una comunidad social como parecen sostener Roman Jakobson y Petr Bogatyrev ${ }^{10}$.

Pero si bien en las lecciones y en la investigación posterior de Lévi-Strauss se a provecha la distribución sincrónico-diacrónica de una masa de relatos orales que contienen un conjunto de rasgos semánticos codificados y opuestos coherentemente en forma de una gramática mítica, éstos han sido obtenidos de lugares y grupos étnicos muy diversos. Se destaca también el hecho de que se emplea indistintamente las informaciones de orden intensional o en comprensión (es decir cotextuales, contenidas exclusivamente en esos objetos empíricos que son los discursos míticos) y otros datos de orden extensional (homologados, esta vez, no más dentro de la dimensión etnoliteraria sino con varios datos contextuales y extràtextuales pertenecientes a la realidad natural zoológica y botánica europea, asiática y americana, a algunas obras literarias -Sófocles, Labiche--, a los discursos metalingüísticos de la ciencia occidental y a ciertos objetos físicos). De ahí que, si bien es propio de la reflexión antropológica participar de algunos principios generales compartidos con la lingüística del discurso y la semiótica, encontramos algunos aspectos de desacuerdo. Efectivamente, en estos dos últimos conocimientos el corpus a estudiar se establece según los llamados parámetros de situación de los informantes, es decir, su localización en una determinada comunidad étnica y lingüística (postulado de la homogeneidad extralingüística: cada etnolecto, sociolecto o idiolecto, es el resultado de los avatares históricos y culturales exclusivos del grupo que lo vive) y los textos mismos que lo componen deben seguir los principios de pertinencia, exhaustividad y selección ${ }^{11}$, ya que los relatos que contienen no son abstraídos de sus circunstancias de producción y de sus condiciones de enunciación. Luego, en cuanto a los campos o conjuntos de términos ligados entre sí por una estructura de relaciones ${ }^{12}$, mientras el antropólogo trabaja con campos semánticos que designan un sector de la realidad mundana o conceptual considerado como articulado de modo diverso por las lenguas ${ }^{13}$, el semiótico lo hace con campos léxicos o conjunto de términos que se relacionan o incorporan en una misma noción expresada por un término más general y que puede servir de término interpretante a todos los otros términos del campo léxico ${ }^{14}$. Por esta razón, en semiótica sólo se admite -para la demostración y explicación disciplinada- la referencialización (=referencia a la enunciación y al componente semántico de las formaciones figurativas, ajena a la dimensión transfrásica de los fenómenos discursivos) y la referenciación (=tanto la referencia horizontal concerniente al 
despliegue sintagmático de los universos discursivos como la referencia vertical que permite describir, en intensión, los distintos planos de "profundidad" de la significación, desde el nivel icónico hasta el nivel abstracto), pero no la remisión o alusión extensional a los posibles referidos del discurso que, desde esta última perspectiva, perturbarían la homogeneidad del análisis.

\section{UNA PROPUESTA SEMIOLINGÜÍSTICA}

Atendiendo a la sugerencia de Lévi-Strauss quien declara que "en esta tentativa de consolidar mitos procedentes de los dos hemisferios hay, lo repito, mucha conjetura. La dejaré pues esbozada, como un campo de investigación abierto a otros para que puedan enriquecerla con nuevos elementos"15 y teniendo en cuenta que ningún objeto de conocimiento (antropológico, lingüístico, histórico, semiótico) es susceptible de agotar por sí sólo el estudio de un objeto empírico común a todas esas disciplinas (por ejemplo, esa "matriz de inteligibilidad"16 que es un relato mítico), he aquí, a modo de complemento, un postulado concreto: el objeto de observación para la lingüística del discurso y la semiótica es únicamente cier to corpus constituido por un número exhaustivo de variantes míticas obtenidas de una sola etnia referidas intratextualmente, en comprensión, a una serie de configuraciones semánticas relativamente estables, pudiendo constituir motivos independientes, desdeel punto de vista intertextual -al mismo tiempo y coincidiendo con el criterio de Lévi-Strauss expuestos en la cita del epígrafe- los resultados del estudio de ese corpus no pretenderán "confirmar la validez de categorías" ni obtener una verdad científica cualquiera, sino simplemente un grado de plausibilidad racional aceptable para los instrumentos de análisis puestos en práctica al describirlos y explicarlos.

\subsection{El corpus}

La serie de variantes que constituyen nuestro corpus, proceden todas de la etnia elegida por él mismo para iniciar su investigación ${ }^{17}$. Estos relatos etnoliterarios se les encuentra, entonces, diseminados en ambos lados de la frontera amazónica peruano-ecuatoriana, lugar donde se ubica el área en que habita la familia Jíbara, perteneciente al tronco Andino del phylum lingüístico ancestral o pre-colombino Andino-Ecuatorial y que comprende, en el lado del Perú, a los grupos étnicos e idiomáticos ${ }^{18}$ :

- Aguaruna (Awajún, Aénts);

- Huambisa (Shuar, Achuar, Maina, Wampís; 
- Achuar (Aente, Achuare, Achuale);

- Jíbaro (del río Corrientes, Jíbaro, Siwaro, Mainu);

- Candoshi-Shapra; y

- Candoshi Murato.

Estos mismos grupos etnolingüísticos se encuentran en el territorio del Ecuador, designados como sigue ${ }^{19}$ :

- Aguaruna, Awajún-shuar o Kantuash-shuar (Aénts);

- Huambisa o Tsuma-shuar;

- Achual o Atschual (Achuara-shuara);

- Jíbaro o Jívaro;

- Shuara o Untsuri-shuar (Muráya-shuar, Yakíya-shuar, Tsumu-shuar, Patúkmai);

- Candoshi-shuar (antiguos Chirapas) y

- Murato.

El corpus reunido se constituirá, pues, con variantes que contienen relatos etiológicos sobre la monogamia, el zapallo, la arcilla y las manchas de la luna pertenecientes a esta familia jíbara. Desde luego, no se pretenderá saturar este corpus incluyendo "todas" las variantes conocidas o posibles de esos relatos; sí, en cambio, será exhaustivo para el área de la amazonía peruanoecuatoriana considerada. Desde este punto de vista, la serie de variantes será tenida, siguiendo las pautas de organización mencionadas, como un todo pertinente, exhaustivo y selecto, lo que no implica que dicho "todo" sea limitado, ya que el corpus puede ser indefinidamente ampliado. Se trata, sin dudas, de la totalidad arbitraria característica de los corpus en ciencias sociales, pero de ningún modo de una supuesta totalidad absoluta ${ }^{20}$ inalcanzable, de hecho, en este tipo de conocimientos.

Dicho esto, como en el caso propuesto los textos de las variantes son dados en las diversas manifestaciones dialectales de la lengua jíbara, la interpretación a realizar será hecha sólo sobre sus traducciones al castellano, regularizadas en su redacción a fin de contar con un corpus homogéneo que, sin embargo, respete las pautas redaccionales de cada una. En ciertos casos se tratará de variantes fonológicas - sea grabadas sea "tomadas al dictado", como dice el P. Guallart- transcritas y luego traducidas término a término; en otros, se tendrá en cuenta el fenómeno de "elasticidad" del discurso (condensaciones y expansiones narrativas $o$, si se quiere, elipsis y catálisis textuales) tanto en las variantes libres como en los resúmenes tomados directamente de los informan- 
tes $^{21}$. El orden no establece naturalmente precedencia ni jerarquía de ninguna clase. Finalmente, cuando la variante conserva en su traducción al castellano ciertos lexemas sustantivos originales y sus significados no aparecen en el mismo texto, ellos serán dados en forma de notas.

Una lectura simple de todas las variantes - o subcorpora-dispuestas en el corpus, permite agruparlas en un primer sub-corpus (1) integrado por una variante (1) que compendia todos los motivos a estudiar; luego, un grupo que reúne una variante con el motivo de los orígenes de la monogamia y la arcilla (Ia-1) y tres más sobre el origen de la monogamia (la-2, la-3, la-4); otro grupo de siete variantes sobre los motivos del origen del zapallo y la arcilla (lb-1, lb-2, lb$3,1 b-4,1 b-5,1 b-6$ y lb-7) y, finalmente un grupo de tres variantes referidas al origen de las manchas de la luna (lc-1, lc-2, lc-3). En un artículo que seguirá a éste, especialmente dedicado a la etiología del arte de la alfarería jíbara, se ampliara el actual corpus con un segundo sub-corpus (II).

\section{SUB-CORPUS I}

\section{- Variante I}

Sol, Etsa, se reunió en la misma casa, jea (1), con su hermano Luna, Nantu, para compartir la misma mujer. Lechuza, Auju, era una mujer muy sensual y quizo ensayar la poliandría. Pensaba: de día sale Etsa y me quedaré con Nantu, que sale de noche. Ella no contó con los celos de Nantu, que la quería toda y sólo para él. El no la dejaba un solo instante y no permitía absolutamente que su hermano Etsa la tocara quedándose con ella aun durante la noche (luna negra). Por cuanto Etsa reclamaba sus derechos nocturnos, Nantu se mostraba siempre más molesto y rencoroso con su hermano y no permitía ni siquiera una sola mirada suya.

Llegó al punto que ya no toleraba su presencia y comenzó a tratarlo mal, para alejarlo de la casa. Un día se enfrentó brutalmente con su hermano, que por ser más fuerte que él, lo dejó muy maltrecho, reventándole un ojo y enturbiándole el otro. Por esta razón la luna tiene una luz tan sombría durante la noche. También Etsa perdió un ojo por un fuerte puñetazo de su hermano. Por esta razón se alejó muy resentido y trepando el bejuco que bajaba del cielo, llamado etsa-náik, se sentó allá arriba, jurando que jamás se hubiera reunido con su celoso hermano. Por esta razón el sol y la luna no andan nunca juntos. Si con un solo ojo el sol, desde allá arriba, alumbra y calienta tanto, con los dos hubiera chamuscado la tierra. 
Antes de marcharse Etsa prohibió la poliandría diciendo:

- La mujer se casará con un solo hombre, lo servirá y lo amará con pasión sin mirar a otros hombres. El hombre debe celar a su mujer y matarla en caso de infidelidad, declarando una guerra a muerte al adúltero.

De aquí entró la costumbre shuar de matar a las mujeres infieles o de castigarlas severamente, traspasándoles los muslos con pinchos de chonta y rapándoles la cabeza. El apasionado Nantu no fue muy feliz con su esposa Auju, por ser ésta una mujer ociosa y golosa. Debía controlar su trabajo, dado que se las daba de gran trabajadora sin haber hecho nada. Además debía decirle lo que debía cocinar, en caso contrario lo dejaba tranquilamente sin almuerzo. Nantu era un buen cazador, no fallaba en sus tiros y traía a la casa abundancia de carne. Un día le dijo a su esposa:

- Recoge esoszapallos, yuzwi (2), madurosy prepáramelos para mi regreso. Colocándose la aljaba, tunta, llena de flechas envenenadas al cuello y con la cerbatana al hombro, salió de caza. Auju cocinó los zapallos y encontrándolos muy dulces, se los comió todos. Luego recogió unos zapallitos tiernos y los cocinó para su esposo. Pasó el día ociosa, sentada en el suelo $\mathrm{y}$, mientras esperaba al esposo, se cosió la boca, para que no la culpara de haber comido sus zapallos. Nantu llegó al anochecer. Entregó las presas cazadas y se dejó caer sobre el tronco chimpí muy cansado. La mujer le sirvió en silencio los zapallos tiernos, apenas pasados por el agua. Esto puso fin a la paciencia de Nantu, que tiró el plato, gritando:

-¿Qué fue de mis zapallos?

Auju sin incomociarse le contestó:

-Yo no los comí, pues ¿con qué boca podía comerlos?

Nantu, al verla con la boca cocida, se tiró sobre ella y con toda su indignación y rabia, le metió los dedos índices en la boca y se la rasgó de oreja a oreja. Por esta razón la lechuza tiene una boca muy ancha. Luego, colocando la ropa que había tejido en su canasta de viaje, pitiak o tukúp, subió al cielo trepando el bejuco etsa-náik. Para no encontrarse con su hermano Etsa, duerme de día y anda de noche.

El zorro, kujáncham (3), se fue a consolar a Auju y se quedó conviviendo con ella. Como una viuda puede convivir sólo con el hermano de su difunto esposo, Auju tenía que ocultar a su hijo las relaciones ilícitas con Kujáncham. Un día dijo a Kujáncham: 
- Trepa el etsa-naiky trae a Nantu, para que salga de caza con su hijo y así pasar juntos los dos sin aprensiones.

Kujáncham, que deseaba mucho a Auju, subió al cielo y agarró a Nantu para llevarlo a la tierra. Nantu indignado contra el concubino desu mujer, en su ardor, le quemó las manos y de un empujón lo tiró a la tierra, en donde se estrelló como un bólido. Hasta ahora podemos ver en la luna esas manchas, que son los dedos chamuscados de Kujáncham, el zorro.

Nantu que estaba en su plenilunio, apareció a los ojos de Auju más hermoso que nunca y comenzó a añorarlo, con todo el deseo de su ser. Se puso a llorar, gritando:

-iAishrua, áishrua! (4)

Como él no le hiciere caso, quiso alcanzarlo en el cielo. En el canasto, chankín (5), más grande que tenía, colocó sus cosas, sus ollas, la tablilla de alfarería y la misma arcilla, junto con los comederos de los perros. Cargó todo a las espaldas y comenzó a trepar el etsa-náik para subirse al cielo.

Dándose cuenta Etsa, para evitar nuevos problemas en el cielo, mandó a la ardilla, kunamp, que royera el bejuco. Auju no estaba lejos del cielo cuando el bejuco se rom pió precipitándola en la tierra, en donde impactó, reventándoseen mil pedazos. Desdeentonces los hombres ya no pudieron subir al cielo. Auju se transformó en una lechuza de boca ancha y otras partes desu cuerpo, cayendo en varias partes de la tierra, se transformaron en arcilla de buena o de mala calidad. Etsa la maldijo desde el cielo, soplando su saliva contra ella (6), después de decir:

-Para que los hombres recuerden que por tu culpa ya nadie puede subir al cielo, oirán tu canto durante las noches de luna repitiendo: ¡Aishrua áishrua, esposo mío! Cuando te pares en donde hay buena arcilla, gritarás: ¡Aújuиuuu tíntiu tíntiu! Pero si te paras sobre arcilla mala, tu grito será: ¡Aújujuju su su su! Así aprendió la mujer shuar que debe evitar los errores de Auju, si quiere ser respetada y amada por su esposo, formando un hogar feliz.

(1) R. Karsten escribe: hea.

(2) Yuwi o Yuví: zapallo, americanismo que, en nuestro caso, designa a la

calabaza comestible andina y amazónica (Cucúrbita máxima).

(3) Kujáncham: véase la nota (2) de la variante Ic-3.

(4) ¡Aishrua, áishrua!: ¡Esposo mío, esposo mío!

(5) Chankín: cesta amplia hecha de un bejuco parecido al mimbre.

(6) Véase la nota (4) de la variante Ib-2.

Pellizzaro, Siro 1990:72-74. 


\section{- Variante Ia-1}

Sol, Etsa, y Luna, Nántu, fueron en tiempos antiguos personas (1) y vivían aquí en la tierra en la misma casa y tenían la misma esposa. Esta última era un pájaro llamado Aoho (2) por los jibaros. A veces Sol estaba con Aoho, algunas veces Luna estaba con ella. cuando Sol abrazaba a Aoho, como era tan cálido, a la mujer le gustaba. Por otro lado, cuando Luna abrazaba a Aoho siendo muy frío a Aoho no le gustaba.

- Eres muy frío-le dijo a Luna- no me gustas.

Sol se burló de Luna y le dijo:

- ¿Por qué eres tan frío? Yo soy muy caliente y por lo tanto le gusto a la mujer.

Luna se enojó mucho y se fue a nayéimbi (3), subiéndose por un bejuco. Al mismo tiempo, le sopló al viento para que sucediera un eclipse y Sol no fuera visible por un momento. La mujer, que pensó que había sido dejado sola, dijo:

-¿Por qué he de permanecer aquí sola? Yo también me iré al cielo.

La mujer consecuentemente empezó a trepar, siguiéndole Luna por el mismo bejuco. Llevaba consigo una canasta llena de núi (4) del tipo que utilizan las mujeres jíbaro para hacer sus vasijas de barro. Aoho estaba muy cerca del cielo cuando Luna notó que ella le seguía.

-¿Por qué me sigues? -preguntó a la mujer. Ya no te quiero tener.

Luna sacudió el bejuco para que se rompiera y la mujer cayó al suelo con la canasta que llevaba. La arcilla se esparció y por donde cayó algo de ella, todavía se encuentra arcilla hoy en día.

Aoho por lotanto, permaneció en tierra y se convirtió en el pájaro que lleva ese nombre.

Su voz dolida todavía se escucha cadá luna nueva, cuando ella llama a su esposo que la abandonó.

Más adelante Sol también trepó al cielo, pero inclusive ahí, Luna está obligada a escapar continuamente del Sol, corriendo sobre montañas y bosques. Nunca pueden marchar juntos y nunca pueden reconciliarse. Por eso Sol es visible durante el día y Luna sólo aparece durante la noche. 
Si Sol y Luna se hubieran puesto de acuerdo para compartir la misma mujer en lugar de quererla cada uno para sí, también entre los jibaros los hombres hubieran podido tener en común una esposa. Pero debido a que los astros se sintieron celosos uno del otro y se disputaron a la misma mujer, los jíbaros no dejan de celarse y combaten continuamente con motivos de las mujeres que quieren poseer (5).

Pero la arcilla, de la cual las mujeres hacen vasijas de barro para las fiestas, tiene su origen en la mujer Aoho, al haber emanado de su alma; y la arcilla que se encuentra hoy en día, ha sido esparcida por Aoho, que luego fue transformada en el pájaro del mismo nombre.

(1) Jíbaros.

(2) Aoho, Auju, Aújuo Aujú: Chotacabras (Caprimulgus; nyctibius grandis); en la variante I-5 se traduce por "lechuza" y en la variante Ib-2 por "sal" que para R. Karsten es, a su vez, "wui".

(3)Nayéimbi: el cielo.

(4) Núi: la arcilla.

(5) La traducción de este penúltimo párrafo perteneciente a la versión inglesa de la variante recogida por $\mathrm{R}$. Kersten, ha sido tomada de la cita directa incluida en la obra de Claude Lévi-Strauss, 1986:23.

Karsten, Rafael, 1989 (1935), II: 588-589.

\section{- Variante Ia-2}

(Eran dos hermanos, ambos eran solteros y buenos mozos). Habían decidido hacer el amor a la mujer por turno, el número de veces y el tiempo igual al empleado por el otro. Si la cosa resultaba bien, se habría permitido que la mujer tuviera el derecho de tomar dos o más maridos.

Pero una noche, Nantu, mantuvo a la mujer bastante tiempo, por lo que Etsa empezó a pelear disputándole la mujer, y le dio varias veces un golpe en el ojo.

Si no era por esto, ambos iban a ser iguales en intensidad de luz y calor. Etsa dijo:

-Por esta razón se tendrá que luchar por las mujeres. Así sopló (1).

(1) Maldijo. Véase la nota (4) de la variante Ib-2.

Rueda, Marco Vinicio, 1983:59. 
- Variante Ia-3

Etsa y Nantu eran un par de hermanos y ambos se casaron con una sola mujer llamada Aúju (1).

La Aúju se viraba un rato con Etsa y otro con Nantu:

-Hermano, abrázale tú también un poco -dijo uno de ellos.

-Tú también después de hacer el amor, date la vuelta.

- Yo también haré lo mismo. Este fue el acuerdo.

Al comienzo hicieron así. Después Nantu acaparó a Aúju a la que tenía abrazada. Etsa quería, a su vez abrazarla pero como vio que estaba en los brazos de Nanty, se dio nuevamente la vuelta.

De nuevo trató de abrazarla, pero al querer hacerlo, sorprendió a Nantu abrazado aún.

Etsa se enojó por esto. Se pelearon los dos hermanos. Etsa pegó en el ojo a Nantu y se fue arriba.

(1) M. Vivicio Rueda traduce Aúju "sal". Luego añade este comentario de R. Tankamash: Entre los shuar, antes, deberian ser las mujeres quienes pudieran tomar dos o más maridos, y no el hombre tener dos o más mujeres.

Rueda, Marco Vinicio, 1983:59.

- Variante Ia-4

Antiguamente Sol, Etsa, y Luna, Nántu, eran gente.

Un día, Etsa se fue a buscar animales. Era muy buen cazador y mataba toda clase de animales.

- Prepárame zapallo, yuwi, para tomar cuando vuelva de la caza-así decía siempre Etsa a su mujer.

- Está bien -contestaba ella. 
Todo lo que le mandaba Etsa, lo cumplía ella rápidamente, pues era muy trabajadora.

Nántu también era muy buen cazador.

Un día apostaron para ver quién de los dos era el mejor.

Conversaron y acordaron así:

-Yo llevaré a tu mujer y la mía irá contigo.

- Bueno -dijo Etsa. Así sabremos quién de los dos es mejor cazador.

Partieron ambos a buscar animales, cada uno con la mujer del otro.

Etsa regresó pronto con gran cantidad de animales.

Nántu no venía y Etsa comenzó a preocuparse.

Por fin, cuando ya era muy tarde, llegó Nántu.

-¿Por qué han tardado tanto?

- Nántu deja escapar a todos los animales. No ha matado ninguno.

Etsa pensó que su mujer era infiel y ya no quiso vivir en la tierra.

-No puedo vivir aquí porque doy mucho calor y los animales y hombres -orirían.

Etsa se marchó al cielo. Nántu quiso acompañar a su amigo pero sequedó más cerquita de la tierra.

Chumap Lucía, Aurelio y García Rendueles, Manuel, 1979, I:202

\section{- Variante Ib-1}

En tiempos antiguos Luna vivía en la tierra, teniendo al pájaro Aoho como esposa. Pero Luna y Aoho no vivían bien juntos y siempre estaban peleando. Un día Luna le dijo a Aoho:

-Prepárame un poco de zapallo para que me lo pueda comer cuando regrese del trabajo esta tarde. 
Luna salió y Aoho cocinó la calabaza, pero haciéndolo se comió los mejores pedazos y sólo dejó los más pequeños y más pobres para su marido. Cuando Luna volvió en la tarde, Aoho le trajo la calabaza en una pininga. Luna, notando la maldad de su esposa, le dijo:

- ¿Por qué me traes estos pedazos de calabazas? ¿Quién se comió los mejores pedazos? Tú seguramente lo hiciste.

Aoho respondió:

- No lo he hecho yo, mira mi boca, si hubiera comido calabaza mis labios estarían todavía mojados.

Luna le dijo:

-Ya que me cuidas tan mal, me iré al cielo por medio de un gran bejuco.

Cuando Aoho vio que Luna la había dejado, decidió seguirle trepando por el mismo bejuco y llevando consigo una canasta con zapallos para prepararlos a su marido.

Cuando Aoho estaba cerca del cielo, Luna dio un sacudón al bejuco, para que se rompiera y Aoho cayó a la tierra. Cuando cayó, todos los zapallos cayeron de la canasta y donde llegaron empezaron a crecer. Desde ese tiempo los jíbaros conocen y cultivan el zapallo.

Pero Aoho todavía vive en la tierra en la forma del pájaro que tiene el mismo nombre y todavía se lamenta por la pérdida de su marido. En toda luna nueva, lo llama cantando canciones con una voz de lamento:

-Aishiru, aíshiru, úruku winya hapána (1).

(1) Aishiru, Aíshiru, úruku winya hapána: "Marido mío, marido mío, ¿por quéme has abandonado?" Nota de R. Karsten:El pájaro (Caprimulgus) en cuestión, es uno de los que atraen particularmente la atención de los viajeros en los bosques del oeste del Amazonas, por su peculiar y triste canto que se escucha especialmente en la nochecuando aparece la luna. Es de esperar que este canto sorprenda a la imaginación de gentes primitivas.

Karsten, Rafael, 1989 (1935), II: 590.

\section{- Variante Ib-2}

Antes Nantu vivía aquí en la tierra y era hombre. Tenía dos mujeres, una era Aujú, otra Kúju (1). Aujú no se llevaba bien con Nantu. Cierta vez Nantu dijo a Aujú: 
- Me voy al monte a trabajar, tú vete a la chacra y tráeme yuvís maduros; cógelos bien maduros y me los traes -así dijo.

Aujú marchó a la chacra, cogió zapallos maduros, sopló el fuego, sacó agua, trajo los zapallos, los cortó y preparó sopa. Habiendo preparado se sentó, acomodándose a la sombra. Sacando la ankuspip (2), tomando, tomando, los acabó. Agarrando zapallos verdes lellevó a él a la casa. Tres le llevó.

Nantu enfadado se fue al cielo por una cuerda de algodón. Aujú dijo:

-Mi marido se va. Yo quiero irme.

Aujú subiendo al cielo, arrancando (la cuerda), cayó a tierra, se estrelló. Dubuig (3) se hizo.

- ¡A Abel! -dijo Nantu. Escupió (4), se fue.

(1) Kúju: Puerco espín.

(2) Ankuspip: cuchara.

(3) Dubuig: Nota de J. M. Guallart: barro de hacer ollas. Las mujeres aguarunas las fabrican mezclando dos clases de arcilla diferentes, añadiéndoles las cenizas de una corteza de árbol.

(4) M. García Rendueles, 1979:57, n. 26, explica: no se trata realmente de escupir sino de soplar fuerte expulsando saliva. Esta acción se realiza siempre al final de un conjuro. Esta significación es válida para todas las ocasiones en que aparezca el verbo usukiáu.

Guallart S. J., José María, 1958:92.

- Variante Ib-3

Había una vez en la selva del Alto Marañón un pájaro nocturno, llamado Auju (1), que comía bastante zapallo. Y el dueño de la chacra cuando se iba a cultivar y limpiar sus terrenos no encontraba nada de zapallo. Y se preguntaba:

-¿Quién estará comiendo mis zapallos?

Y se encontró al pájaro nocturno y el dueño de la chacra le preguntó: -¿Eres tú el que come mi zapallo? 
Y el pájaro nocturno contestó:

- ¿Cómo vuy a cumer yu tu zapallu si yu nu tengu buca? ¿Acasu sin buca se puede cumer alguna cusa?

Auju, el pájaro nocturno, hablaba así porque se había cosido la boca.

Y otra vez, cuando nadie le veía, el pájaro nocturno se iba a la chacra a comer zapallo.

Y el dueño de la chacra era la luna llena.

Y la luna cuando el pájaro se marchó, se subió al cielo trepando por una soga.

El pájaro nocturno viendo que la luna estaba subiendo al cielo, corrió y también comenzó a subir agarrándose a la soga con su pico.

La luna que subía primero llegó al cieloy viendo que detrás venía también subiendo Auju, le cortó la soga.

En ese momento, el pájaro nocturno, como estaba bien gordo de tanto comer zapallo, se cayó a tierra y se reventó su barriga.

Y al caer al suelo, el pájaro nocturno se convirtió en arcilla.

Así murió el pájaro nocturno por estar robando zapallo.

Y el dueño de la chacra de zapallo era la luna llena.

(1) Auju: Nota de J. L. Jordana Laguna: Ave de plumaje azulado. Entre los aguarunas existe la creencia de queal principio de los tiempos Auju fue una de las dos mujeres de Nantu, la luna.

Jordana Laguna, José Luis, 1974:51-52.

\section{- Variante Ib-4}

Antiguamente, Nántu vivía con una mujer glotona, panzuda y con una boca que le llegaba de oreja a oreja. Auju (1) se llamaba.

Tenían una chacra grande de zapallo, pues a Nántu le gustaba mucho el chapo (2) de zapallo. 
-Ya pronto estarán maduros los zapallos y podré tomar chapo -decía a menudo Nántu.

A los pocos días Nántu mandó a su mujer recoger los zapallos maduros para que le preparase chapo, pues quería tomarlo cuando regresara de la caza.

Aujú se fue a la chacra y, cogiendo zapallos verdes y maduros, preparó un buen chapo.

Como era muy glotona lo quizo probar y, con su boca tan grande, pronto terminó todo.

Para que Nántu no se enfadase, preparó más chapo con los zapallos verdes y, para engañarle, se pegó los labios con cera de abeja, dejándose sólo un agujerito parecido a la boca de los peces.

Cuando llegó Nántu con un wáshi (3) muerto, pidió chapo pues traía mucha sed. Al probarlo, dijo:

- ¿Por qué no has preparado chapo con zapallos maduros?

- He buscado por toda la chacra y no he encontrado ninguno. ¿Crees que yo me los puedo comer con esta boquita tan pequeña?

Lo mismo sucedió varias veces.

Un día Nántu se fue a la chacra y recogiendo todos los zapallos maduros que encontró, los dejó amontonados. Luego avisó a su mujer para que los recogiese y preparase chapo pues él se iba de caza.

Al atardecer llegó Nántu muy cansado pero contento de poder, por fin, probar buen chapo. Mas, después de beberlo, dijo:

-¿Qué ha pasado con los zapallos maduros que dejé amontonados en la chacra?

- Busqué por todos los lados y nada encontré -contestó ella.

- Si sólo tú vas a la chacra ¿quién puede robarlos?

- Pues con esta boquita tan pequeña que tengo, yo no puedo comerlos. 
Pero, nuevamente, Auju había preparado buen chapo para ella y otro, con los zapallos verdes, para Nántu.

Al día siguiente Nántu se fue también de caza y pidió a Auju que le preparase chapo.

Pero se quedó cerca de la casa, escondido, para ver qué hacía la mujer.

Al atardecer entró en la casa como si volviese del monte.

Auju le ofreció chapo para beber y dijo:

-Sólo he encontrado zapallos verdes.

Nántu, lleno de cólera, tiró la pininga (4) y dijo:

-Ya no quiero vivir más contigo.

Saliendo fuera de la casa se sentó en un bejuco llamado nántu-wakán (5). Antiguamente este bejuco era pequeño; pero cuando Nántu se sentó encima em pezóa crecer y crecer hasta quedarse comoahora. Cuando dejó de ascender, Nántu siguió subiendo por un hilo que bajaba del cielo.

Auju quiso seguir a su marido. Metió todo lo que había en la casa -los kutanes (6), las ollas, la leña...-en una gran canasta y comenzó a subir por el bejuco. Como estaba embarazada subía lentamente.

Nántu esperó a que estuviese bien alta y, de pronto, cortó el hilo. Auju cayó en un barranco por donde pasaba un riachuelo y, al chocar contra el suelo, su barriga reventó y todo el zapallo que tenía dentro seesparció por todas partes, convirtiéndose en el barro con el que ahora las mujeres hacen las ollas. Y ella se convirtió en el pájaro Auju. Por eso, cuando hay luna llena, se oye el canto de Auju:

-¡Waaa! ¡Aishua! jaishua! (7)

Pero es un canto ridículo porque Nántu le maldijo.

(1) Auju: Nota de M. García Rendueles: es el ave Aymamá, de plumaje blanco y negro. Es de hábitos nocturnos.

(2) Chapo: Bebida preparada con plátanos maduros cocidos y desleídos en agua. Cuando se deja fermentar es alcohólica.

(3) Wáshi: maquisapa (Ateles sp.) Cuadrúmano de color negro y extre- 
midades desproporcionadas; las toráxicas tienen sólo cuatro dedos, mientras que las traseras presentan cinco.

(4) Pininga, pinígo, pinín, vasija de barro cocidoy decoradocon dibujos geométricos de colores vivos. Se utiliza únicamente para servir masato.

(5) Nántu-wakán: por donde subió Nántu.

(6) Kután: banquillo de una sola pieza, generalmente de madera de topa. La parte inferior seahueca en forma cóncava de tal manera que quedan dos bordes estrechos en los que el banquillo se asienta. La parte superior se aplana para mayor comodidad. Un pequeño saliente en forma de punzón en alguno de los lados superiores facilitará su transporte de un lugar a otro.

(7) ¡Waaa! ¡A ishua! ¡aishua!: ¡Ay! ¡Maridito!, ¡maridito!

Chumap Lucía, Aurelio y García Rendueles, Manuel 1979, I:210-213.

\section{-Variante Ib-5}

Nantu, al ir a soplar los pájaros, dijo a su mujer Aúju:

-iEspérame con unos zapallos maduros cocinados, a mi vuelta!

-¡Bueno!-dijo Aúju.

Cuando regresó Nantu, Aúju se comió los zapallos maduros y sirvió zapallos tiernos. Aúju se había cosido la boca para decir después quecon qué boca podía haber comido los zapallos maduros.

Disgustado Nantu dijo:

-¿Acaso pedí zapallos tiernos?

Y subió arriba (1).

También Aúju, cargando todas sus cositas y objetos de cocina subió arriba haciendo sonar tatar, tatar, por donde había subido Nantu, llorando amargamente:

-¡Ay! ¡mi marido!, ¡ay, mi marido!...

Kunampe (2) cumpliendo lo dicho por Nantu, le cortó el bejuco y la pobre 
Aúju se precipitó nuevamente a la tierra. Y los fragmentos de Aúju se transformaron en arcilla, dicen (3).

(1) M. Vinicio Rueda consigna un comentario del informante y de A. Karákras: Al cielo. Al irse tal vez desgarró la ropa. (Los shuaras) subían por una escalera de bejuco. Podían visitar a los seres bienaventurados. Después no fue posible porque el bejuco fue cortado por Etsa. Y esto lo recuerdan los shuaras cuando encuentran bejucos en la montaña.

(2) Kunampe o Kunamp: ardilla (Wichink: Sciureus sp).

(3) M. Vinicio Rueda conserva este fragmento narrado por A. Karákras y E. Tseman: Se comió los zapallos maduros porque estaba en cinta. Al ser cortado el bejuco, los fragmentos de la madre se convirtieron en arcilla buena y los del niño en arcilla mala y poco durable.

Rueda, Marco Vinicio, 1983: 105-106.

\section{-Variante Ib-6}

Etsa y Auju eran esposos que vivían en la selva. Un día, Etsa saliendo para la cacería dijo a su esposa que le "diera cocinado" un guiso de yuwi. Etsa se fue de caza. Auju fue a la huerta cerca de la casa, recogió zapallos y preparó el guiso esperando a su esposo. Sintiendo hambre comenzó a comer. Terminó con lo mejor del guiso y dejó los zapallos tiernos para su esposo.

Al llegar el marido le pidió de comer. Auju le sirvió los zapallos tiernos que habían quedado. Etsa enojado le gritó:

-¿Así es de comer? ¿Acaso que yo voy a comer?

Luego cogió a Auju y le cosió la boca. La sacó de casa y le pegó. Se alejó de la casa y se metió entre los árboles de la selva. Subió al cielo por una escala de bejuco. La esposa entró corriendo en casa, cargó con todo lo que pudo. Subió tras de Etsa por la misma escala. Pero su esposo le cortó la escala y ella se cayó. Gritó espantada queriendo decir "esposo mío" pero no logró decir más que "Auju". Y se convirtió en el pájaro que lleva este nombre. Nosotros sabemos que esto es verdad porque Auju dejó muestra de todo. 


\section{-Variante $\mathrm{Ib}-7$}

Etsa se había casado con una mujer llamada Auju. Un día, Etsa, al salir de caza le dijo que le preparara un guiso de zapallo. Cuando Etsa volvió de caza hambriento, su esposa se había comido los zapallos maduros y había dejado los tiernos para su esposo. Etsa enojado salió de casa a toda prisa y se volvió al cielo. Subió una escala de bejuco y la cortó para que los hombres no pudieran subir tras él.

Barrueco, Domingo, 1985: 22.

\section{- Variante Ic-1}

El pájaro (1) en tiempos antiguos vivía en la tierra como mujer y la luna, que en esos tiempos también vivía en la tierra, como un hombre, era su amante. Luna iba de visita a ver a Anga todas las noches y dormía con ella. Para reconocerlo, anga una noche ennegreció las mejillas de luna con huituc (2). Luna trató de limpiarse las manchas negras de las mejillas, pero como no lo pudo hacer, se avergonzó y dejó la tierra y la mujer para siempre, trepando al cielo por un gran bejuco. Inclusive hoy en día las manchas negras son visibles en la cara de la luna. Como todos pueden ver. Pero Anga, que fue abandonada, se lamentó amargamente con la pérdida de su amante. Todavía vive en la tierra en forma de pájaro y en cada luna nueva se escuchan sus notas de lamento, las mismas notas con las cuales las mujeres indígenas se lamentan por su marido muerto:

-Nyuca curilla , nyuca cusulla, imamant hicúscani, imata tucúshcani (3).

(1) Sacha anga: del quechua "halcon". Noobstanteque esta variante tiene como personaje a Anga, R., Karsten la titula "El mito Aoho como es corriente entre los canelos"; Claude Lévi-Strauss, 1986:24, advierteque la variante "procede de los indios canelos de lengua quechua, vecinos de los jíbaros e influenciados por ellos".

(2) Huituc, Huito o Súwa: Genipa americana, fruto para tinturar. M. García Rendueles proporciona esta información: Planta rubiácea de forma arbórea. Su fruto raspado y cocinado da una tinta de color azul oscuro. Se usa, lo mismo que el ipák (achiote: Bixa Orellana; las semillas de este arbusto proporcionan un pigmento rojizo) como pintura corporal para diversos rituales y como distintivo para la guerra. Se le atribuyen también propiedades medicinales. Sirve para teñir los hilos de algodón destinados a diversos tejidos. La mujer Súwa, cansada de vagar por la selva, se convirtió en la planta homónima. 
(3) Es decir: "Mi maridito, mi querido, ¿por qué me has abandonado?, ¿qué será de mí?"

Karsten, Rafael, 1989 (1935), II:591.

- Variante Ic-2

Antiguamente Luna, Nántu, vivía en la misma casa que su ubán (1). Nántu tenía su mujer pero la ubán aún estaba soltera. Nántu dormía con su mujer; la ubán dormía sola en otra cama; los demás familiares dormían en otras camas. Todos en la misma casa.

Por la noche Nántu se levantaba y se iba a la cama de su ubán. Ella lo aceptaba pero no sabía quién era y, aunque intentaba agarrarlo fuertemente para descubrirlo cuando amaneciera, Nántu siempre lograba escapar y volver a su cama antes de que se viese nada.

Una noche, Nántu volvió a la cama de su ubán; aunque dormía, notó que alguien intentaba forzarla. La mujer quiso agarrar al hombre pero, nuevamente, Nántu consiguió escapar.

Por la mañana la mujer avisó a su dukún (2):

-Alguien viene a mi cama cuando estoy dormida, pero nunca logro ver quién es.

La madre le dijo:

-Coge un fruto de súwa y cuandoél esté contigo, píntale la cara. Entonces sabremos quién es.

La mujer fuea buscar súway, raspándolo bien, lo dejó preparado cerca de su cama.

Aquella noche Nántu volvió a la cama de su ubán. Cuando lo sintió, agarró súwa y le pintó la cara. Nántu volvió rápidamente a su cama.

Cuando amaneció todos vieron la cara de Nántu pintada de negro.

- ¡Seguro que eres tú el que viene a mi cama! -le dijo la ubán.

Todos los familiares dijeron a Nántu: 
-¿Por qué teacuestas con tu ubán?,¿no te da vergüenza acostartecon ella? Nántu avergonzado por haber sido descubierto, se fue a buscar a su mujer que había ido a la chacra.

-Mujer, hazme chapo de zapallo para tomar.

- ¿Acaso ves bastante zapallo maduro para hacer chapo? -le contestó la mujer.

Nántu regresó triste a la casa. Vio a su hijita y le dijo:

-Hija, me voy al cielo; ven conmigo.

Haciendo un nije (?) subió al cielo con su hija avergonzado por haberse acostado con su hermana.

Nántu todavía tiene su cara manchada de negro, desde que su ubán se la pintó con súwa.

La mujer de Nántu se llamaba Auju.

(1) Ubán o umán: hermana y también hija de apán (padre y hermano del padre). Se utiliza siempre de hombre a mujer.

(2) Dukún: madre, hermana de la madre y mujer del hermano de la madre.

Chumap Lucía, Aurelio y García Rendueles, Manuel, 1979, I:205.

\section{-Variante Ic-3}

Mi apán (1) así me contó y él no puede hablar de lo que no conoce.

Luna, Nántu, se cayó (del cielo), dicen. Caído Nántu, estaba alumbrado.

El Kujáncham (2) dijo:

-Yo voy a llevar (a Nántu) para que, dejándole (en la casa), mi hijito lo observe.

¡Tapit!, lo agarró. 
Antiguamente Nántu calentaba como Sol, Etsa; así era. Por eso (la ropa mojada) se extendía por la noche (para secarla); así dicen que pasaba. Como Nántu era así, por eso, jtapit! lo agarró.

¿No ves que la mano del kujáncham, con los dedos bien abiertos, está marcada (en la luna)? ¿(No te has fijado) que la mano del kujáncham está marcada en el pecho de Nántu?

¿No te has fijado que está marcada?

El dedo pulgar de la mano, el pulgar, también los otros cuatro dedos de la mano, todos ellos, están marcados (3). Fíjate bien después, pensando en esto.

Después (de agarrar a Nántu), la mano del kujáncham, (quedando) bien caliente, secaba la ropa. Así dicen.

En la noche (Nántu) alumbraba como Etsa; así dicen. Así era.

- Vetea ver (si en las trampas) hechas con chambira (4) que hemos colocado, ha quedado lazado algún yámpits (5)-dijeron (al kujáncham).

Diciendo eso, le mandaron. ¿Por qué no habrá pensado bien?

Llegando, (vio) que ningún yámpits había caído (en las trampas).

Como (las trampas) eran para agarrar porel cuello(a las aves, el kujáncham) dijo:

- iAcaso con esta clase de trampas puede caer el yámpits!.

Para probar (la trampa) metió despacito su pene. Topando el tutik (6), ¡shakáut! (soltándose), por la cabeza del pene, ahí donde se estrecha, ¡kaet! quedó atrapado.

¿Por qué habrá querido probar si, como no pesaba tanto, elevándose, iba a quedar colgado?

Entonces, jalando el palo, ipajat! rompiéndolo, (se cayó).

¿Por qué quiso probar si luego no iba a regresar a su casa (con su pene amarrado)?

Como ya estaba por morir, ;puwáuuuuu! alumbraba cada vez menos.

(Cuando vieron una lucecita, pensando que kujáncham ya regresaba), 
dijeron:

-Ya viene, ya viene.

Estando así, estando así, ¡puwáuuuu! alumbraba amarillo. Estando así, estando así, ahí en el monte ¡dewáaaaa! se encendía despacito: (la luz nuevamente) se perdía.

- ¿Por qué hará así? Vete a ver -dijeron.

Llegando, vio (al kujáncham) con su pene amarrado, caído, casi muerto, enfriándose, enfriándose.

Cuando desató el pene, revivió.

Porque sucedió así, (ahora el kujáncham tiene la mano) fría, dicen.

Ya está. Basta.

(1) Véase la nota (1) de la variante Ic-2.

(2) Kujáncham: Nota de M. García Rendueles: zarigüeya (Dydelphis virginiana), animal nocturno que posee una glándula segregadora de un líquido fétido.

(3) El dedo pulgar de la mano se llama mun uwéj; los otros cuatro juntos se llaman tsajam uwéj.

(4) Chambira: en aguaruna, batté (Astrocaryum chambira), palmera espinosa de unos $15 \mathrm{~m}$. de altura y $20 \mathrm{~cm}$. de diámetro. De sus hojas se obtiene material textil que, debidamente torsionado, se utilizará para hacer pitas (cuerdas) con las que se fabricarán diversos objetos; también se utiliza para coser. Con las hojas se haceel chipát: depósito para guardar en el carcaj los virotes envenenados. En su tronco se crían los suris o larvas comestibles.

(5) Yámpits: paloma.

(6) Tutik: palito atravesado que pone en funcionamiento la trampa.

Chumap Lucia, Aurelio y García Rendueles, Manuel, 1979, I:206-209.

\subsection{Los motivos}

El criterio fundador del análisis semiolingüístico que sigue es, como lo he venido haciendo hasta ahora, la concepción de los relatos etnoliterarios y de literatura oral peruanos en tanto bastidores narrativos que acogen sea un motivo sea series de motivos. El motivo es, desde este punto de vista, un armazón estructurado (no "estructuralista": de hecho, un relato o cualquier otro objeto pragmático no es una estructura per se; asume, sí, las estructuras -entidades autónomas de relaciones internas (Hjelmslev, Greimas)-que cada objeto de 
conocimiento disciplinado ensaya para describirlo y explicarlo según sus propios fines) definida por una configuración cuya forma sintáctica es fija y por ello puede ser extraído del relato mayor en que se encuentra, lo cual permite observar su alcance tanto particular -al tomar para sí y manifestar los valores intraculturales de la etnia o grupo social que lo emite-como universal, por sus propiedades migratorias interculturales. La configuración es, entonces, un micro-relato "cristalizado" que posee una organización sintáctico-semántica autónoma, capaz de formar parte de un relato mayor y por ese hecho asume las "significaciones funcionales" propias dela narración en quese halla inserto ${ }^{22}$. Esta forma sintáctica estable es un Programa Narrativo canónico o de base que no excluye la concurrencia de otros Programas Narrativos simples - presupuestos y necesarios-según las variantes textuales que los incluyen. Los enunciados narrativos que componen dichos programas, son determinados por relacionesfunciones susceptibles de incorporar semánticamente ciertos recorridos figurativos a ser organizados hipotácticamente y las categorías temáticas genéricas y específicas que les otorgan su sentido; allí los términos llamados actantes son, al contrario, manifestados por categorías figurativas (los actores) y figurales que pueden cambiar según las variantes sin afectar la estructura del motivo.

Cabe advertir que resulta casi una excepción el hecho de que el relato contenido en una variante presente, a nivel del discurso, un motivo único (como sucede con el motivo del origen de la monogamia en la variante Ia-2); lo corriente es que la variante contenga uno o más motivos y, por esa circunstancia, ciertos enunciados pertenecientes a un motivo interfieran los de otro sea con una alusión simple a temas o figuras ajenos (en la variante la-4, cuyo motivo es también el origen de la monogamia, encontramos un enunciado textual que remite al motivo del origen del zapallo) sea con unidades mayores como, por ejemplo, una parte de la configuración de otro motivo (por ejemplo, la variante Ic-2 que corresponde al motivo del origen de las manchas de la luna, incluye también un episodio de los motivos del origen del zapallo y la arcilla). Es decir que la variante, siendo un objeto de habla, un discurso, al reunir varios motivos en secuencia los presenta seriados pero no de modo totalmente independiente, sino que ciertos enunciados textuales de unos pueden traslaparse en los otros.

\subsubsection{Origen de la monogamia}

El corpus que antecede ha sido organizado, entonces, a partir del gran relato etnoliterario I. De él se desglosarán cuatro motivos etiológicos: el origen de la monogamia, el origen del zapallo, el origen de la arcilla y el origen de las manchas de la luna. 
Un examen somero de las secuencias que contiene el motivo del origen de la monogamia en las variantes I y la Ia-1, nos muestra de inmediato la discursivización de cierta configuración anímica (o pasional). De hecho, en estas variantes la narración comienza (ab initio) con un episodio del tiempo mítico primordial, etapa donde los "actuales" seres cósmicos eran "personas". Etsa y Nántu (o Nantu) tienen ambos el mismo rol temático de maridos de Auju (Aoho), pudiendo por ello ser intercambiables sin conflicto (de hecho, son protoactantes "intersujetos"); Auju, porsu parte, ostenta el rol temático ${ }^{23}$ deesposa de ambos (es decir, de protoactantes sujeto-objeto). Mientras se mantiene ese estado inicial, el discurso es neutro, vale decir, no hay allí contenido anímico alguno ya que las llamadas "fuerzas del sentir" (o foria, sincretismo de la articulación euforia/disforia) entre los tres permanecen estables (son actantes "protensivos"o"potencializados"); sin embargo, la intriga se inicia (mediaad finem) cuando Auju dinamiza ese estado al manifestar un ánimo inédito que deja aflorar cierto temperamento tímico inquieto o disposición afectiva manipuladora - una especie de sismo emotivo que afecta el imaginario del funcionamiento actancial estable-cuyo rol actancial es el de sujeto destinador y su rol patémico ${ }^{24}$ es la atracción (del "calor") vs repulsión (del "frío") sea la sensualidad ("poliandría") que provocan -en la estructura profunda-la tensividad fórica, la inestabilidad de la relación entre sus maridos constituidos -ahora en la estructura de superficie-como sujetos destinatarios rivales entre ellos:

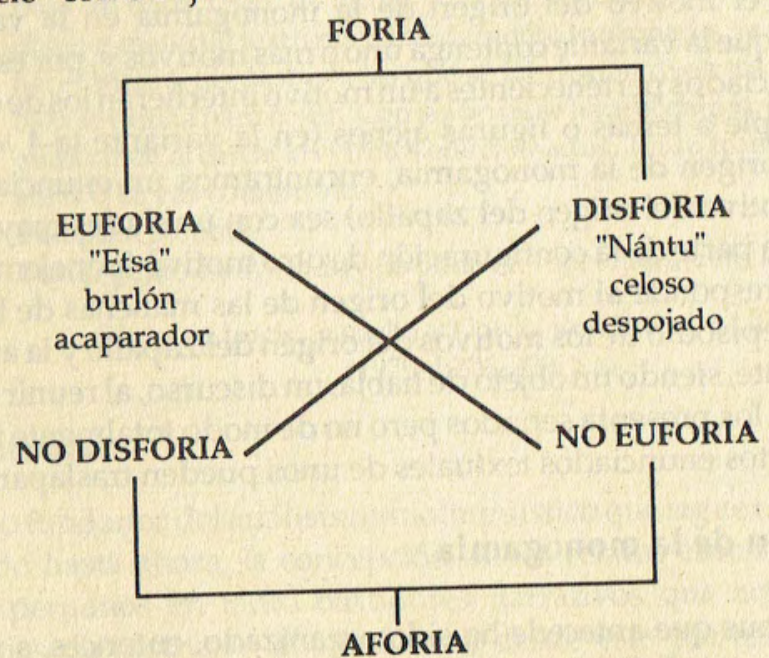

Etsa, entonces, al consentir a la seducción de Auju asume el rol patémico eufórico de burlón y el rol temático de acaparador mientras que Nantu los roles disfórico de celoso ("enojado", "molesto", "rencoroso") y temático de despojado. 
Esta tensión va en aumento, hasta producirse la quiebra del sentido ( $a d$ finem), la catástrof $\mathrm{e}^{25}$ que hace bascular la foria contenida. El desequilibrio y, por lo tanto, la distensión surge al inclinarse el relato por la disforia, dispositivo patémico negativo que al repercutir en el plano de la categorización cognoscitiva, desencadena la transformación fundadora del Programa Narrativo:

$$
\text { PNB: } F\left[S_{0}\left(S_{1} \cap \mathrm{O} \cap \mathrm{S}_{2}\right) \rightarrow\left(\mathrm{S}_{1} \cup \mathrm{O} \cup \mathrm{S}_{2}\right)\right]
$$

PNB: Programa Narrativo de Base; F: Función transformadora; $\mathrm{S}_{0}$ : Sujeto Operador: Auju; $\mathrm{S}_{1}$ : Sujeto de Estado I: Etsa; S2 : Sujeto de Estado 2: Nantu; O: Objeto de Valor: Auju; []: enunciado de /hacer/; ( ): enunciado de estado; $\cap$ : Conjunción; $\cup$ : Disjunción y $\rightarrow$ : función de /hacer/.

Por lo visto en este PNB el actor Auju sincretiza las funciones actanciales de destinador y objeto en relación a los dos sujetos ${ }^{26}$, y de sujeto operador respecto a la transformación. Es este último rol actancial que se vierte en la competencia de Auju (como consecuencia necesaria desu manipulación), lo que produce el cambio de la situación original: la sanción del programa indica que, en estas variantes, Etsa representa el rol patémico definitivo de resentido y Nántu el de enojado, roles que precisamente los convierten en astros irreconciliables, como anti-sujetos entre sí, pero con sus roles temáticos específicos y positivos gracias a sus recategorizaciones temáticas en las categorías figurativas del Sol y Luna respectivamente. Si resentirse es, según el diccionario, "ofenderse o sentir enfado por algo" $y$ "hecho de acordarse con animosidad de los males, de los daños padecidos", enojarse equivale a "movimiento de ira o resentimiento contra una persona", con lo cual ambas definiciones son parasinonímicas y se traslapan entre sí formando un pequeño campo léxico determinadoglobalmente por el descontento, es decir, el disgusto o desagrado que no llega a convertirse en el estado de ánimo cólera ${ }^{27}$. Ese descontento se da, pues, como respuesta a la categoría temática específica ofensa ("herir a alguien en su dignidad (honor, amor propio)") recibida mutuamente-ya que ambos actúan en base a los roles temáticos de ofensores y ofendidos entre sí-, pero es la acción de Auju como sujeto operador de la prueba decisiva, la queocasiona la ofensa primera en I contra Etsa y en Ia-1 contra Nantu, y, por lo tanto, frente a ella siempre mantienen el rol temático de ofendidos.

La sanción que recae sobre Auju es, por su parte, negativo-transitiva al sentir ella misma -en su competencia-igualmente un estado de ánimo de disgusto o desagrado por el desenlace de la situación, pero en una forma más grave que las anteriores. Se trata de la contrariedad (insatisfacción y decepción) 
al dejar la categoría temática específica del acompañamiento y sufrir la derrelicción (roles temáticos: abandonada, desamparada) lo cual incide en su pérdida de los roles actanciales de destinador, objeto y sujeto operador, reteniendo únicamente su rol mínimo de anti-sujeto de estado y la adquisición de un nuevo rol temático, esta vez negativo, por medio de la figura icónica del pájaro Chotacabras, Lechuza o Aymamá. De tal manera que la transformación anímica de orden polémico culmina en una sanción que trastoca la estructura completa $^{28}$, pues no sólo cambia el estado inicial en su contrario, sino que produce la metamorfosis o cambios de naturaleza de los actores humanos (personas) en cósmicos los primeros y zoema la última, redistribuyéndose también las relaciones interactanciales - antes protagónicas, ahora antagónicas-, todo lo cual acarrea finalmente la eterna disjunción entre los seres celestes y terrestres, como entre ellos en sus respectivos planos existenciales.

Sigamos ahora el proceso de la configuración anímica desde el punto de vista de la serie de identidades modales transitorias que constituyen a los sujetos modales. En la etapa inicial (incoativa) regida por la neutralización anímica, la competencia de los protoactantes muestra un sincretismo de la fusión y la escisión, una verdadera modulación de las valencias que orientará luego, en la segunda etapa, el titubeo o ansiedad propia de la inquietud. Efectivamente, állí no encontramos ninguna modalización definida, los actores están relacionados entre sí por un establishment triangular y equidistante planteado por un "destino" desconocido, escatológico. La intriga se inaugura -se abre-, decía con el rol patémico inquieta, es decir, con el vertimiento en la competencia del protoactante Auju de la oscilación contradictoria entre los valores modales del / querer / (a Etsa) ${ }^{29}$ y el /no-querer/ (a Nantu) ("Cuando Sol abrazaba a Aoho, como era tan cálido, a la mujer le gustaba. Por otro lado, cuando Luna abrazaba a Aoho siendo muy frío a Aoho no le gustaba"), situación que perdura (etapa durativa) mientras / puede/ mantenerla. Se trata, así, de un / querer-poder-hacer/ que transcurre hasta que el / saber/ actualizante que informa la competencia de Nantu ("Eres muy frío -le dijo [Nántu] a Luna- no me gustas") y Etsa ("¿Por qué eres tan frío? Yo soy muy caliente y por lo tanto le gusto a la mujer") -cuyos roles patémicos son, como vimos, de burlón y celoso respectivamente- llega al punto del desenlace (etapa terminativa): en un caso (I) la sanción es inmediata, Nantu (competencia: /saber/ - /no-querer hacer/, o sea, "no querer continuar la relación") abandona a Auju, es decir, categoriza la pérdida del actante objeto ${ }^{30}$ cuya competencia se modaliza a su turno e inmediatamente con el /no-poder hacer/; en la otra variante (Ia-1) el relato se expande o cataliza con el episodio del enfrentamiento entre los hermanos-maridos -que incluye el motivo del desafío ${ }^{31}-$ y el 
abandono de Auju esta vez por Etsa, quien se halla también modalizado por el /saber/ - /no-querer hacer/. Pero además, como constatamos, las competencias de Nantu y Etsa presentan los roles patémicos finales del resentimiento y el enojo entre ellos, estados de ánimo que se modalizan, primero, por el /no querer estar/ conjuntos y finalmente por un /hacer-estar/ separados de modo definitivo; ello, por repercusión de los acontecimientos del plano celeste en el terrestre, termina por afectar a los seres humanos.

En el epílogo del motivo de la variante Ia-1, la sanción de Etsa, ahora en su calidad de demiurgo, establece el "nuevo orden" o coherencia social gracias a la modalización de su competencia con el eje modal deóntico de la prescripción o / deber hacer/ respecto de la monogamia y de prohibición o / deber no hacer/ de la poliandría -que instituyen el régimen familiar, uno bajo el enfoque positivo y el otro negativo- y con ella la modalización, en la competencia de los actantes con figuración terrestre, del / no deber no hacer/ en relación a la primera y / no deber-hacer/ en relación a la segunda. La modalización deóntica positiva de la sanción aparece en I como el /deber estar/ juntos, fundador de la institución familiar y estigmatizador de todo lo que pueda perturbarla ("-La mujer se casará con un solo hombre, lo servirá y lo amará con pasión sin mirar a otros hombres. El hombre debe celar a su mujer y matarla en caso de infidelidad, declarando una guerra a muerte al adúltero"). Esta sanción final en el plano cognoscitivo afecta, desde luego, al plano pragmático del relato: "De aquí entró la costumbre shuar de matar a las mujeres infieles o de castigarlas severamente, traspasándoles los muslos con pinchos de chonta y rapándoles la cabeza". La misma estructura elemental de la significación deóntica aparece en la variante Ia-1 (entre las secuencias correspondientes al motivo del origen de la arcilla) pero como consecuencia general de la polémica entre Etsa y Nantu, reordenación que, por cierto, no afecta en nada a la economía narrativa del relato; en los planos cognoscitivo y pragmático: "Si Sol y Luna se hubieran puesto de acuerdo para compartir la misma mujer en lugar de quererla cada uno para sí, también entre los jíbaros los hombres hubieran podido tener en común una esposa. Pero debido a que los astros se sintieron celosos uno del otro y disputaron a la misma mujer, los jíbaros no dejan de celarse y combaten continuamente con motivo de las mujeres que quieren poseer". Estos textos disponen así el eje de los contrarios (Prescripción-Prohibición) del modelo constitucional de las relaciones sexuales en la sociedad jíbara, modelo que será completado más adelante al examinar la secuencia de la variante I dedicada al motivo del origen de las manchas de la luna (cf. 3.2.4). 
Además de los expuesto es posible constatar, también en el nivel de la estructura profunda, el cambio de deixis llevada a efecto por la transformación en el nivel de superficie. Como hemos visto, en la etapa incoativa del relato se observa un contrato de convivencia o concurrencia y la etapa terminativa culmina en una posición polémica, de conflicto que se perpetuará hic et nunc; de hecho, el texto que acabo de citar de la variante Ia-1 sólo llega a indicar una presunción de acuerdo susceptible de lograrse después del enfrentamiento, pero se concluye que él nunca será realizado. Diagramemos ahora este desarrollo en la estructura profunda, empleando el cuadro semiótico correspondiente a las relaciones contractuales y polémicas donde la flecha describe el proceso planteado en el Programa Narrativo y la línea simple la presunción del convenio:

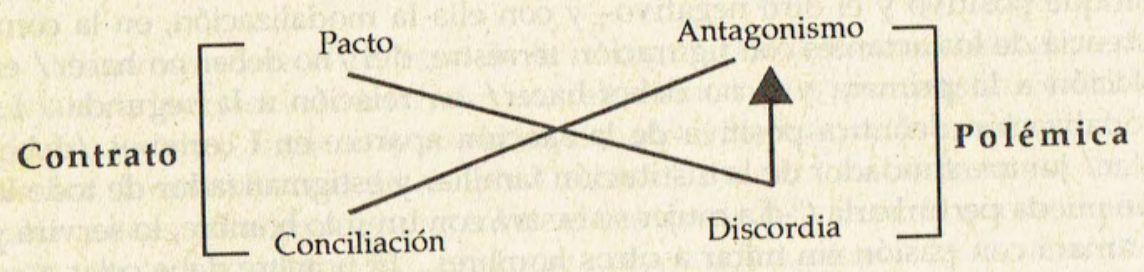

Examinemos en seguida las otras variantes del motivo del origen de la monogamia consignadas en nuestro corpus, las mismas que demuestran claramente la independencia de este motivo y su propiedad de emigrar e insertarse otros relatos más amplios. La variante Ia-2 es así una síntesis completa de la configuración que define este motivo y sólo acentúa ciertas propiedades estructurales descritas, por ejemplo, en la etapa incoativa se remarca la calidad protoactancial de los actores (Etsa y Nantu son "hermanos solteros" a quienes no liga una relación poliándrica sino una categoría temática simple, la decisión-tomada en algún momento y lugar del hic et nunc propio de la existencia por preterición ${ }^{32}$ - de poseer a "la mujer" (cuyo emplazamiento estructural es el de Auju) "el número de veces y el tiempo igual al empleado por el otro") y se agregan algunos roles temáticos ("solteros"), patémicos y estésicos ("buenos mozos") asignados a Etsa y Nantu. En la siguiente, Ia-3, la intriga no comienza con la inquietud de Auju sino con el acaparamiento prolongado de ésta por Nantu, ahora manifestado y no solamente presupuesto como en I y Ia-1; correlativamente, es Etsa quien asume el estado anímico de celoso ("enojado") y, en el plano de la presuposición, el de despojado. Por lo visto, las funciones anímicas, actanciales y modales se redistribuyen entre el trío de actores, pero sin afectar la estructura del Programa Narrativo. 
Por último, la variante Ia- $4^{33}$ propone igualmente una fase incoativa de armonía contractual neutra y protensiva implícita, pero esta vez entre cuatro términos. Etsa y su mujer de un lado, Nántu y la suya del otro, donde los varones cumplen la misma función de ser protoactantes intersujetos destinadores y las mujeres de protoactantes sujetos-objetos destinatarios. En esta primera parte también se incorpora a la competencia de los actores ciertas categorías temáticas éticas por medio de ciertas categorías figurales o abstractas: Etsa y Nántu son "buenos cazadores", sin embargo como más adelante Nántu "no ha matado" ningún animal se incorpora en su competencia la conducta y el rol temático de "mal cazador"; la mujer de Etsa era "muy trabajadora" pero también al final del texto, según el criterio de Etsa, "le era infiel"; al contrario, de la mujer de Nántu no se dice nada. Si cotejamos estas categorías con las del mismo motivo en I, encontramos que Nantu "era buen cazador, no fallaba en sus tiros y traía a la casa abundancia de carne" pero recibe mal trato de su mujer Auju quien "le sirvió en silencio los zapallos tiernos, apenas pasados por agua"; Auju, por su lado, era "ociosa y golosa. [Nantu] Debía controlar su trabajo, dado que se las daba de gran trabajadora sin haber hecho nada". Al organizar este grupo según el criterio rector determinado por las categorías axiológicas de la foria, obtenemos la siguiente disposición:

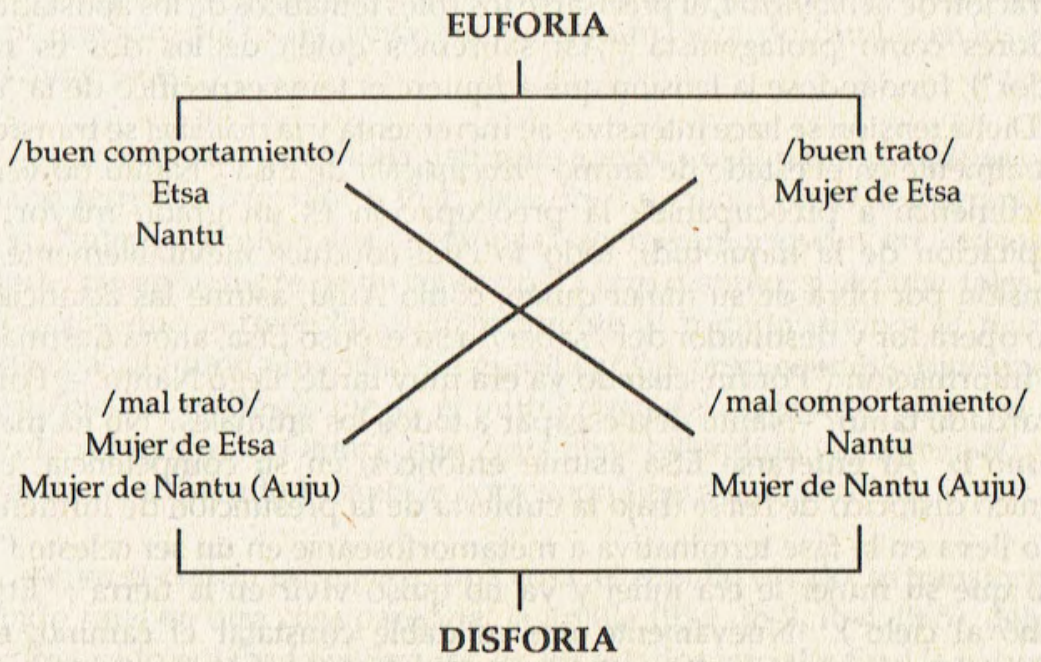

Esta estructura elemental de los valores de conducta (comportamiento, trato) propuestos por los textos, se fijan estereotipadamente en la competencia 
de cada actor; ellos, además, a fuerza de reiterarse de variante a variante, llegan a constituir verdaderos prototipos del obrar ético y finalmente si se considera el conjunto de los ciclos míticos propios de la cultura jíbara, se observarán los arquetipos correspondientes. Limitándonos al alcance de nuestros corpus, diremos que, por ejemplo, Auju (Chotacabras) es un actor prototipo del /mal comportamiento/ y del /mal trato/, mientras Etsa (Sol) lo es del /buen comportamiento/; Nantu (Luna) por lo general es tornadizo como las fases de este satélite de la tierra; en ciertas ocasiones observa /buen comportamiento/ y en otras / mal comportamiento/; por último, la mujer de Etsa tiene también un trato inconstante, como se repite en Ib-6 donde Auju representa ese rol o cuando ella ocupa el papel de esposa de Etsa y Nantu.

Prosigamos con el examen de Ia-4. Su fase durativa surge con un acuerdo de competencia que es bastante expandido en comparación a la secuencia correspondiente de las variantes anteriores: aquí aflora la inquietud bajo cubierta de una categoría temática específica, la apuesta de cacería, que desde luego incluye el rasgo semántico definitorio del "pacto" y comprende el intercambio de los protoactantes sujetos-objetos. Nótese que este intercambio no supone en modo alguno la modificación del estado de ánimo reinante, la "concordia"; es un intercarnbio de valencias, no de valores. La categoría temática específica rivalidad-propiamente dicha- aparece como una primera aceleración de la inquietud, al precisarse los roles temáticos de los apostadorescazadores como protagonista ("Así sabremos quién de los dos es mejor cazador"), fundándose la tensión que adquiere el tema específico de la "cacería". Dicha tensión se hace intensiva, se incrementa y la rivalidad se transforma gradualmente en el estado de ánimo preocupación de Etsa ("Nantu no venía y Etsa comenzó a preocuparse": la preocupación es un grado mayor, una precipitación de la inquietud), todo lo cual conduce inevitablemente a la distensión por obra de su mujer quien, como Auju, asume las actancias de sujeto operador y destinador del / saber/ a su esposo Etsa, ahora destinatario de la información ("Por fin, cuando ya era muy tarde, llegó Nántu. - ¿Por qué han tardado tanto? -Nántu deja escapar a todos los animales. No ha matado ninguno"). Al enterarse Etsa asume entonces, en su competencia, el rol patémico disfórico de celoso (bajo la cubierta de la presunción de infidelidad) que lo lleva en la fase terminativa a metamorfosearse en un ser celeste ("Etsa pensó que su mujer le era infiel y ya no quiso vivir en la tierra"; "Etsa se marchó al cielo"). Nuevamente nos es dable constatar el camino, en la estructura profunda, que lleva del "pacto" a la "discordia" y finalmente al "antagonismo" sin dar pie a una posible reconciliación ("Nántu quiso acompañar a su amigo pero se quedó más cerquita de la tierra"). 
Queda por explicar la categoría temática específica del "calor" y la "calidez" de Etsa que en las variantes I y la-1 es eufórica y en la variante Ia-4 es disfórica ("-No puedo vivir aquí porque doy mucho calor y los animales y hombres morirán"). Fuera del hecho de que su aspecto eufórico se da en relación a Auju y el disfórico frente a los seres terrestres (cosa que se anota igualmente en otro parágrafo de I: "Si con un solo ojo el sol, desde allá arriba, alumbra y calienta tanto, con los dos hubiera chamuscado la tierra") y por lo tanto no puede ser un término complejo al depender de distintos niveles semánticos, la ambivalencia de esta propiedad natural de Etsa se debe a que ella es positiva en un programa narrativo de "seducción" cuyo estatuto es la mesura, pero es negativa en un anti-programa de "destrucción" donde prima el exceso ${ }^{34}$. De esta manera la coherencia del relato es constatable aún en el contenido de una sola categoría temática, significado orientado por el sentido (mesurado/excesivo) del enunciado que lo rige en cada caso.

\subsubsection{Origen del zapallo}

El motivo precedente muestra de manera concreta la intervención de la configuración anímica -cambios de estados de ánimo-en la dimensión tímica del relato. Los motivos que ponen en escena el origen del zapallo y de la arcilla, sin excluir sus propias configuraciones anímicas, aprovechan algo más la dimensión pragmática del relato dando cuenta, a su manera, del cambio en los estados de las cosas; ellas:

a) mantienen su distinta naturaleza intocada al pasar del plano celeste al plano terrestre (zapallo: I, Ib-1, Ib-6, Ib-7; arcilla: I, Ia-1), a diferencia del motivo anterior donde dos "personas" se metamorfosean en "astros"; no obstante, pasan siempre de un contexto ${ }^{35}$ a otro distinto: si $a b$ initio tales cosas son objetos que pertenecen exclusivamente al mundo divino, ad finen son transferidas al mundo humano sin modificar sus propiedades y funciones. El ejemplo clásico es, desde luego, el mito griego del origen del fuego (al robar Prometeo el fuego del Olimpo que Zeus tiene escondido, lo entrega tal cual a los hombres, sufriendo la sanción correspondiente a su acto ${ }^{36} ; 0$,

b) en el estado primigenio una cosa, el zapallo cocido, se transforma en el estado final en otra cosa parecida, la arcilla ( $\mathrm{Ib}-2, \mathrm{Ib}-3, \mathrm{Ib}-4, \mathrm{Ib}-5)$, debido a que como ya lo notaba Lévi-Strauss, en los estados inicial y final la naturaleza de la cosa -la calidad de "informe"- permanece igual (aunque como se ha visto en 2, esa propiedad la asigne sólo a las lianas, a la arcilla y a los excrementos). 
A partir de estas observaciones, veamos más de cerca las variantes que nos tocan relativas al origen del zapallo. Tomemos en I la secuencia correspondiente a la configuración cuyo tema principal es el zapallo ya preexistente, sin embargo, en el mundo del relato. Ahí la competencia de Nantu ostenta el rol patémico totalizador de apasionado, definido en este discurso como "poseído o perturbado por algunas pasiones", por ejemplo, los estados de ánimo molestia y rencor, pero especialmente los celos frente a Etsa y a causa de Auju. No obstante, en la etapa incoativa, a pesar de que Nantu ha logrado su propósito de ahuyentar a Etsa y quedarse solo con Auju, el texto nos dice que "no fue feliz con ella". A partir de esta indicación, se amplían ciertos roles temáticos, por ejemplo, Auju además de ser golosa es ociosa (rol patémico y ético: abúlica,modalizado con el /no querer hacer/ nada), al contrario de Nantu que es buen cazador (rol patémico y ético: diligente, modalizado con el /saber poder hacer/ de la cacería además de la pericia que ella supone) y hermoso (rol patémico y estésico: atractivo, / hacer querer/ conjuntivo) a la vez que Auju lo "añora" (rol patémico: añoranza, definida como "soledad, aflicción causada por la ausencia" y modalizada por el /querer $/{ }^{37}$ y el / no poder hacer/ conjuntivo), o detalles en la sanción como el ascenso de Nantu al cielo llevando "la ropa que había tejido en su canasta de viaje" lo cual enfatiza su diligencia. Quizás lo más notable sea, cosa característica de esta variante I fuertemente patemizada, la incorporación en las competencias de Nantu y Auju de otros estados de ánimo no descritos hasta ahora. Veamos someramente sus alcances.

¿Qué ocasiona la reacción violenta de Nantu? Pues la categoría temática específica y tímica de la avidez (definida como "ansia, deseo vehemente" e ilustrada en el texto con el sintagma "se los comió todos (los zapallos maduros)"; volición y realización temática genérica: /querer hacer/ -/saber hacer / /poder hacer $/-/$ hacer/) en la competencia de Auju que contradice el episodio signado por la categoría temática específica "pedir" o "solicitar" por parte de Nantu (categoría modal deóntica: / deber hacer/) y la correspondiente "desobedecer" (/no querer hacer/) en el comportamiento de Auju al servir a Nantu "en silencio los zapallos tiernos, apenas pasados por agua"; esto "puso fin a la paciencia de Nantu, que tiró el plato, gritando: - ¿Qué fue de mis zapallos? Auju sin incomodarse le contestó: -Yo no los comí, pues ¿con qué boca podía comerlos? Nantu, al verla con la boca cosida, se tiró sobre ella y con toda su indignación y rabia, le metió los dedos índices en la boca y se la rasgó de oreja a oreja. Por esta razón la lechuza tiene una boca muy ancha". Así la etapa incoativa del relato presenta a Nantu y Auju disjuntos ya de Etsa pero en un estado de disforia, de "discordia" actualizada entre ellos que no 
llega al enfrentamiento y al "antagonismo" gracias a que la compentencia del primero se halla patemizada por la paciencia definida como "disposición del espíritu de quien sabe esperar sin perder la calma"38 , esto es, modalizada por el / poder querer ser y estar / que caracteriza a la espera, a la perseverancia y, como en nuestro caso, a la "cólera contenida". Ese estado se prolonga en el transcurso de la fase durativa, pero como ya ha ocurrido en anteriores oportunidades, en ella la tensión va en aumento hasta hacerse excesiva e intolerable y, como no deja de observarlo Greimas, es la impaciencia modalizada por el /saber/ (al darse Nantu cuenta del engaño de Auju), lo que incentiva tanto la fase terminativa como la aparición del rol patémico propio de la cólera $^{39}$ en su competencia (/poder hacer/ de la agresividad orientada hacia la afirmación de sí y la destrucción del otro): de ahí la transformación violenta del estado de conjunción en el estado de disjunción entre los sujetos y el súbito paso de la "discordia" al "antagonismo" con la sanción correspondiente. En la estructura superficial del relato encontramos la siguiente configuración entre los distintos sujetos de estado que acabamos de ver, Programa-boceto del Programa principal a estudiar luego:

$$
\text { PN: } F\left[S_{0}\left(S_{1} \cup S_{2} \cap S_{3}\right) \rightarrow\left(\varnothing-S_{2} \cap S_{3}\right) \rightarrow\left(S_{2} \cup S_{3}\right)\right]
$$

PN: Programa Narrativo; F: Función transformadora; $\mathrm{S}_{0}$ :Sujeto Operador: Nantu; $S_{1}$ : Sujeto de Estado: Etsa; $S_{2}$ : Sujeto de Estado: Nantu; $S_{3}$ : Sujeto de Estado: Auju; ø: ausencia del Sujeto de Estado $S_{1}$. Los símbolós de las operaciones son los mismos del PNB anterior.

Aquí Nantu como actor sincrético desempeña en la fórmula el doble rol actancial de sujeto operador y sujeto de estado; es de notar, por otro lado, que en este relato el zapallo ya existente motiva únicamente la cólera de Nantu y su huída al cielo, pero no da origen a la arcilla por la inserción del motivo de las manchas de la luna entre la secuencia estudiada y la que describo más adelante al tratar el segundo caso.

A continuación de I tenemos la variante Ib-1 que desarrolla el Programa Narrativo de Base correspondiente al origen del zapallo, pero levemente humedecido por los estados de ánimo. Ab initio, en la fase incoativa tenemos el mismo estado: Luna tiene como esposa al pájaro Auju (Aoho), pero "no vivían bien juntos y siempre estaban peleando", es decir, un estado de conjunción entre los sujetos que ya prefigura de modo latente la disjunción 
entre ellos o sea la "discordia", hecho que los ubica de inmediato en la deíxis de la polémica. La etapa durativa desenvuelve la tensión hasta producirse el "antagonismo" declarado siempre originado por la avidez de Auju: "Luna le dijo: -Ya que me cuidas tan mal, me iré al cielo por medio de un gran bejuco" y la aparición de la fase terminativa con la sanción del alejamiento por parte de Luna; Auju recibe consecuentemente el rol patémico de la solitaria (/querer estar/ acompañada, pero/no poder hacer(lo)/). Al verse abandonada decide buscar la "conciliación" trepando el mismo bejuco, pero esta vez "llevando consigo una canasta con zapallos para prepararlos para su marido" y así reparar la falta o, según Propp, la carencia que dio lugar a la intriga descrita. La sanción consiste, como antes, en la caída de Auju: "todos los zapallos cayeron de la canasta y donde llegaron empezaron a crecer. Desde ese tiempo los jibaros conocen y cultivan el zapallo", mientras que ella "vive en la tierra en la forma del pájaro que tiene el mismo nombre y todavía se lamenta por la pérdida de su marido". Esta sanción es importante porque indica justamente el origen del zapallo que siendo primordialmente de propiedad exclusiva del mundo divino (celeste: arriba), pasa a ser $-a b$ ovo- patrimonio del mundo humano (terrestre abajo), transformación espacial que, como recordamos, liga analógicamente este relato al de Prometeo y el origen del fuego. He aquí, pues, el Programa principal del motivo:

$$
\text { PNB: } \mathrm{F}\left[\mathrm{S}_{0}\left(\mathrm{~S}_{1} \cap \mathrm{S}_{2}\right) \rightarrow\left(\mathrm{S}_{1} \cup \mathrm{S}_{2}\right)\right]
$$

PNB: Programa Narrativo de Base; F: Función transformadora; $\mathrm{S}_{0}$ : Sujeto Operador: Luna; $S_{1}$ : Sujeto de Estado: Nantu; $S_{2}$ : Sujeto de Estado:Auju (Aoho).

Remarcaré ahora que en esta variante no se hace reminiscencia alguna al origen de la arcilla, salvo a su preexistencia en el presente enunciativo del relato ("Cuando Luna volvió en la tarde, Aoho le trajo la calabaza en una pininga"): se trata estrictamente del origen del zapallo entre los hombres. Algo semejante se constata en el contenido de la variante Ib- 6 en que la pareja conformada por Etsa y Auju es originalmente humana $y$, a causa del episodio del "engaño" -que estudiaré más adelante, al tocar el motivo del origen de la arcilla- de Auju respecto a la preparación del zapallo, producido nuevamente por su rol patémico y ético de ávida ("terminó con lo mejor del guiso"), Etsa es quien estatuye la sanción invertida (I: "rasgar" / Ib-6: "coser": "cogió a Auju y le cosió la boca. La sacó de la casa y le pegó"), retirándose luego al cielo. Auju, por su parte, se "convirtió en el pájaro que lleva este nombre". Por último, la corta variante Ib7 presenta a la pareja Etsa y Auju desunida por el conocido episodio del zapallo 
y la avidez del Auju ("se había comido los zapallos maduros"); en la secuencia ad finem, Etsa corta la escala de bejuco "para que los hombres no pudieran subir tras él". Resumiendo, la figura del zapallo juega, ora temporal (antes/después) ora espacialmente (arriba / abajo) de modo independiente, pudiendo, sea limitarse a su propia organización temática y axiológica, sea por transformación, a ser el elemento origen de la arcilla como veremos luego.

\subsubsection{Origen de la arcilla}

La variante $\mathrm{Ib}-2$ nos presenta, a lo menos, dos diferencias frente al motivo del origen de la monogamia: según ese motivo, inicialmente se trataba del estado de poliandría (Etsa y Nantu comparten a Aoho), en este motivo se trata del estado de poligamia (Nantu "tenía dos mujeres, una era Aujú, otra Kúju"). La segunda diferencia es de orden estructural: el estado de poligamia no es neutro, es decir que los actantes no son protensivos ya que allí mismo la competencia de Nantu conlleva el rol actancial de sujeto destinador en relación a Aujú y Kúju quienes, a su vez, ostentan las competencias actanciales sincréticas de destinatarios y objetos pero, además, si Kúju y Nantu son sujetos de estado entre sí, la relación entre Aujú y Nantu es la de anti-sujetos. En efecto, ¿qué es lo que determina que la intriga se inicie aquí tan deinmediato, sin ninguna etapa previa? Es el hecho de que la disforia informa las competencias de Nantu y Aujú con la "discordia" ("Aujú no se llevaba bien con Nantu"), es decir que el relato no se plantea en la deíxis del contrato sino de frente en el de la polémica. Ello afecta por lo tanto las competencias de ambos sujetos con el rol patémico de la repulsión (la competencia del actor Kúju que, por presuposición lógica, estaría informado por la atracción, desaparece totalmente del relato) que no implica, sin embargo, la ruptura o -en términos semióticos- la disjunción actancial entre ellos. Unidos por el estado de las cosas (son pareja) y desunidos por el estado de ánimo (el rol patémico del encono mutuo), el Programa Narrativo se plantea entre la "discordia" y el "antagonismo" correspondiendo este último, en el plano narrativo, al estado de disjunción final. Por lo tanto, es la tensión iniciada con la repulsión (categoría modal volitiva: / no querer estar/ conjunto) que se hace cada vez más intensa -como en el motivo del origen del zapallo-a través de la "prescripción" u "orden" de Nantu (/deber hacer/) y la "desobediencia" (/no querer hacer/) con el rol patémico y ético de la ávida en la competencia de Aujú (Nantu encarga a Aujú conseguirle zapallos maduros -los zapallos están ya dados-pero ella misma se los prepara y come), lo cual, comparado con las otras variantes donde se resume el comportamiento de Aujú, aparece en Ib-2 totalmente figurativizado: 


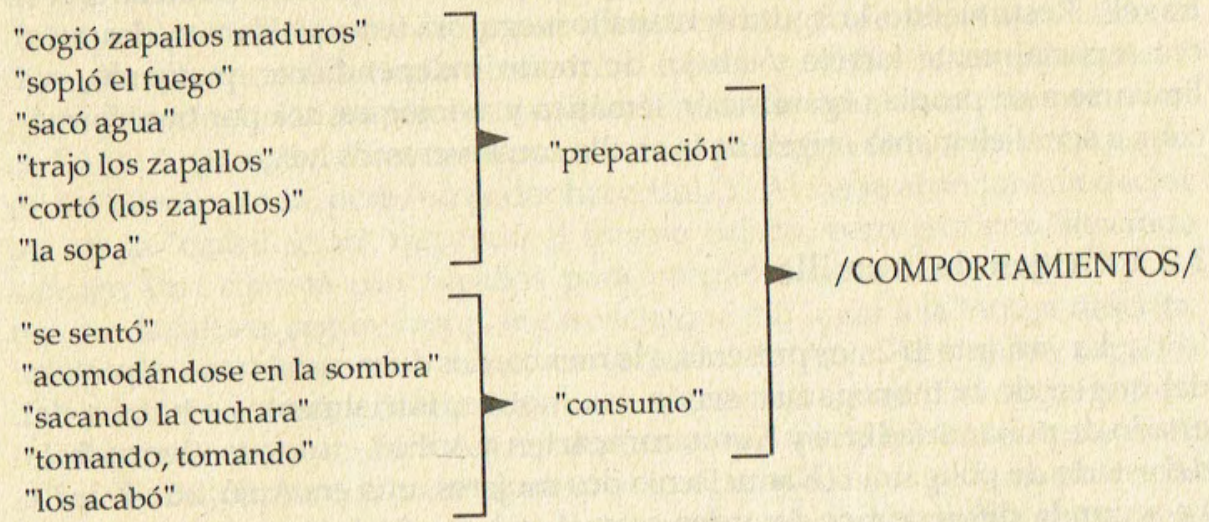

Este es un ejemplo claro de saturación figurativa de un tramo del relato, frente al enrarecimiento de las figuras en las otras fases (figurales) del mismo que, ciertamente, están discursivizadas pero de modo muy escueto, abstracto. Tal es el caso de la continuación del relato en que Nantu se "da cuenta" de la "desobediencia" de Aujú y hace patente su estado de disjunción (competencia cognoscitiva: indiferencia: / no saber / vs percatarse: /saber/) enfadándose, fenómeno anímico que termina por hacer explícito, en una primera instancia, el Programa del motivo:

$$
\text { PN: F }\left[\mathrm{S}_{0}\left(\mathrm{O}_{1} \cap \mathrm{S} \cap \mathrm{O}_{2}\right) \rightarrow\left(0_{1} \cup \mathrm{S}-\varnothing\right)\right]
$$

PN:Programa Narrativo; F: Función transformadora; $\mathrm{S}_{0}$ Sujeto Operador:Nantu; $0_{1}$ : Objeto de Valor: Aujú; S: Sujeto de Estado: Nantu; $0_{2}$ :Objeto de Valor: Kúju; ø: ausencia del Objeto de Valor $\mathrm{O}_{2}$.

Detengámonos un momento en el enfado de Nantu que desemboca en la transformación del Programa Narrativo ("se fue al cielo por una cuerda de algodón"). El enfado es considerado por los diccionarios en tanto "enojo, alteración de ánimo que se manifiesta con reacción, ostensible [tal es nuestro caso] o no, contra lo que la causa" y también en cuanto "ira, impresión desagradable y fastidiosa que nace en el ánimo", definiciones que, sin duda, la colocan como un término más del campo léxico del descontento ya visto en el motivo del origen de la monogamia, adquiriendo así todas las consecuencias estudiadas. Por lo 
demás, a diferencia de ese mismo motivo, luego del estado sancionador que determina el rol patémico de la categoría temática específica derrelicción en la competencia de Aujú, ésta ensaya establecer un contrato de "conciliación" con Nantu; por eso la competencia de Aujú se modaliza, con el / querer hacer estar/ ("-Mi marido se va. Yo quiero irme"), pero como su intento fracasa, ese / querer estar/ con el marido, se remodaliza en un / no poder hacer/ que da lugar precisamente a la aparición de la arcilla ("Aujú subiendo al cielo, arrancando (la cuerda), cayó a tierra, se estrelló. Dubuig se hizo"). El relato termina con el conjuro de Nantu, epílogo que enfatiza la sanción conclusiva del demiurgo.

Como se ve, la categoría figurativa "zapallo" a pesar de que precede a la categoría figurativa "arcilla", no tienen en esta variante una relación manifiesta -aunque sí presupuesta- entre ambas: el zapallo, ya preexistente, no se transforma de manera explícita y directa en la arcilla; es Aujú la que se convierte en el "barro de hacer ollas". Con todo, ya se esboza la homologación simple:

\section{zapallo: Aujú :: Aujú : arcilla}

que la variante Ib-3 del mismo motivo se encargará de perfeccionar.

Efectivamente, la variante Ib-3 presenta de inmediato a Auju bajo la figura icónica del "pájaro nocturno" y al zapallo tal cual; la luna (o la "luna llena ocupa, por cierto, el papel de Nantu en las otras variantes) se expresa, en cambio, por medio de un actor antropomorfizado, "dueño de la chacra". El relato se inicia con una carencia y la satisfacción de esa carencia, es decir, con dos Programas Narrativos de uso, presupuestos y necesarios entre sí y ambos presupuestos y necesarios respecto del Programa Narrativo de Base, al cual se agrega un tercer Programa Narrativo también de uso que coloca a los dos sujetos en relación de conjunción ("Y se encontró al pájaro nocturno"):

$$
\begin{aligned}
& \mathrm{PNU}_{1}: \mathrm{F}\left[\mathrm{S}_{01} \longrightarrow\left(\mathrm{S}_{1} \cup \mathrm{O}\right)\right] \\
& \mathrm{PNU}_{2}: \mathrm{F}\left[\mathrm{S}_{01} \longrightarrow\left(\mathrm{S}_{2} \cap \mathrm{O}\right)\right] \\
& \mathrm{PNU}_{3}: \mathrm{F}\left[\mathrm{S}_{02} \longrightarrow\left(\mathrm{S}_{1} \cap \mathrm{S}_{2}\right)\right]
\end{aligned}
$$

PNU: Programa Narrativo de Uso; F: Función transformadora; $\mathrm{S}_{\mathrm{O} 1}$ : Sujeto Operador: Auju; $\mathrm{S}_{02}$ : Sujeto Operador: luna; $\mathrm{S}_{1}$ : Sujeto de Estado; luna; O: Objeto de Valor: zapallo; $\mathrm{S}_{2}$ : Sujeto de Estado: Auju. 
La manifestación de los PNU en la secuencia ab initio de nuestro relato, reitera en este motivo la exclusión del estado neutro y protoactancial que hemos observado en el motivo del origen de la monogamia. Así, este rela to coloca a los dos sujetos de estado en posiciones antagónicas respecto al objeto común, el zapallo, comportándose entre sí como anti-sujetos: mientras Auju se halla conjunto con ese objeto, la luna se encuentra disjunta de él. ¿Quién ocasiona este desajuste o, mejor, desbarajuste incoativo? Ciertamente Auju quien ahora como el actor "pájaro nocturno" sincretiza en sí las funciones de sujeto de estado y sujeto operador en los dos primeros PNU. A nivel de la estructura elemental de la significación, estos PNU concomitantes son posibles gracias a la incorporación en ellos del cuadro constitucional de la veridicción:

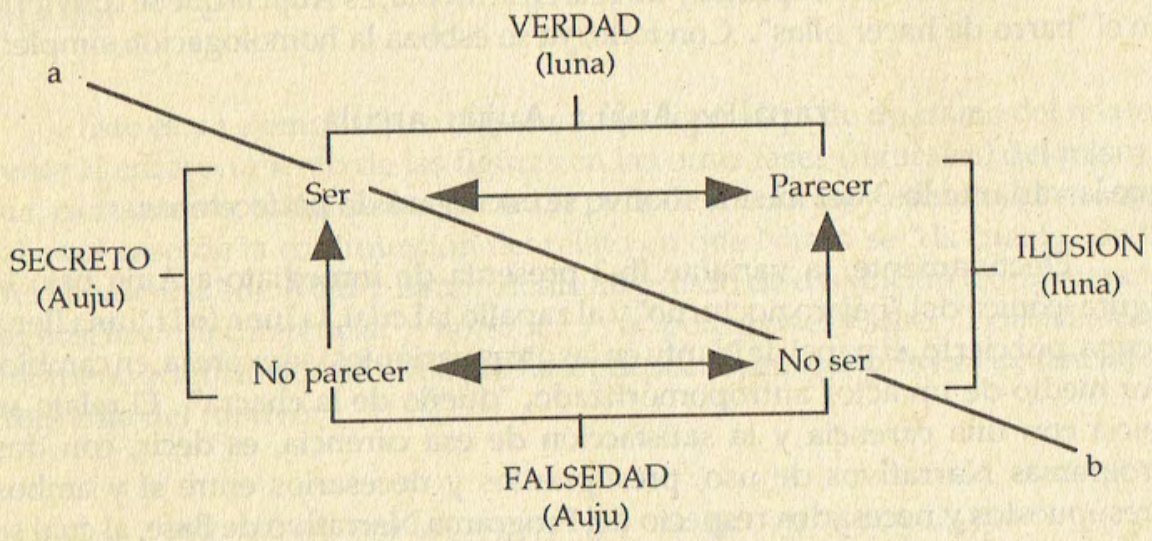

A través de esta esquematización podemos constatar que la luna ocupa, durante la primera etapa del motivo, la deíxis de la ilusión (/no ser/+ /parecer/: "Y el dueño de la chacra cuando se iba a cultivar y limpiar sus terrenos no encontraba nada de zapallo. $Y$ se preguntaba: - ¿Quién estará comiendo mis zapallos? Y se encontró al pájaro nocturno y el dueño de la chacra le preguntó:- ¿Eres tú el que come mi zapallo? Y el pájaro nocturno contestó:-¿Cúmu vuy a cumer yu tu zapallu si yu nu tengu buca? ¿Acasu sin buca se puede cumer alguna cusa?") mientras que Auju congrega la deíxis del "secreto" (/no parecer/+/ser/) y el eje sub-contrario "falsedad" (/no parecer/ + / no ser/), o sea el secreto que guarda frente a la luna -quien a su vez presupone, en su competencia como $\mathrm{S}_{1}$ del tercer PNU, la categoría temática ética de la perplejidad - y la falsedad que el enunciador descubre al enunciatario- 
lector ("Auju, el pájaro nocturno, hablaba así porque se había cosido la boca"). En el primer tramo del relato se trata, en suma, de una manipulación por la categoría temática ética decepción (engaño: "falsedad o falta de verdad en lo que se dice o hace") y en la competencia de Auju el rol temático correspondiente del deceptor o engañador ${ }^{40}$.

La fase durativa del relato se da con la reiteración de las acciones de Auju -o prueba deceptiva-cuyo rol ético-temático es otra vez el de la ávida ("Y otra vez, cuando nadie le veía, el pájaro nocturno se iba a la chacra a comer zapallo"), gula que termina por causar el apartamiento de la luna y con ello el establecimiento del Programa Narrativo de Base en el motivo estudiado ("Y la luna cuando el pájaro se marchó, se subió al cielo trepando por una soga"):

\section{PNB: $F\left[\mathrm{~S}_{0}\left(\mathrm{~S}_{1} \cap \mathrm{S}_{2}\right) \longrightarrow\left(\mathrm{S}_{1} \cup \mathrm{S}_{2}\right)\right]$}

PNB: Programa Narrativo de Base; F: Función transformadora; $\mathrm{S}_{0}$ : Sujeto Operador: luna; $S_{1}$ : Sujeto de Estado: luna; $S_{2}$ : Sujeto de Estado: Auju.

El sujeto operador de este Programa Narrativo principal no es, pues, otro que la luna, quien asume en su competencia la categoría de la verdad (eje de los contrarios; /ser/+/parecer/) al reaccionar de su perplejidad y sustituirla por la categoría temática ética de la determinación. De esta manera, la disjunción entre los sujetos de estado en el plano superficial del relato produce la quiebra o división del cuadro constitucional de la veridicción en dos partes (a-b) que, a su vez, coloca a Auju bajo la posición de la categoría contractual y a la luna bajo la categoría polémica. Los protagonistas transformados en antagonistas y resuelta la disjunción entre ambos, procede la etapa terminativa que ciertamente contiene la sanción. Como ya sucedió en Ib-2 y en las otras variantes, el estado sancionador indica el rol temático de la desamparada en la competencia de Auju; ésta ensaya, a semejanza de Ib-2, establecer un contrato de "conciliación" con la luna (/querer hacer estar/ conjunta con la luna), designio fracasado (/no poder hacer/) que determina, ahora directamente, al zapallo como causa y origen de la arcilla por medio de un proceso:

a) espacial ("cayó": arriba: celeste / abajo: terrestre),

b) tiempo-existencial ("murió": antes: vida / después: muerte) y

c) figurativo, conducido por la categoría temática específica, ética y tímica de la avidez que crea dentro de la competencia de Auju una tensión en aumento ("comer zapallo" - "bien gordo") dirigida hacia una distensión inevitable ("reventó su barriga"). 
Todo ese proceso puede ser resumido y diagramado del siguiente modo:

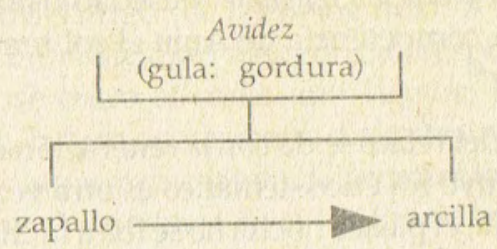

esquema en el cual la flecha indica la transformación de una figura por la otra.

Las dos variantes siguientes $-\mathrm{Ib}-4$ y $\mathrm{Ib}-5$ - simplemente expanden 0 catalizan el contenido del relato de la variante $\mathrm{Ib}-3$ la cual, al diseñar el Programa Narrativo de Base del motivo, adquiere la calidad de variante canónica. Sin embargo, la fase de la sanción en $\mathrm{lb}-4$ y lb-5 tiene algunas particularidades a destacar, por ejemplo, en $\mathrm{Ib}-5$ quien corta el bejuco por el cual sube Aúju no es el propio Nantu sino que esta función es confiada a otro actor, la ardilla (Kunampe), quien por esta razón representa el rol actancial de sujeto operador delegado, como sucede igualmente en I; en seguida, al subir Nántu al cielo, la abandonada Aúju lo persigue pero esta vez "metió todo lo que había en la casa -los kutanes, las ollas, la leña...- en una gran canasta y comenzó a subir por el bejuco" según Ib-4 y "cargando todas sus cositas y objetos de cocina subió arriba haciendo sonar tatar, tatar, por donde había subido Nantu" según Ib-5. En la primera de estas dos variantes, Aúju al caer "en un barranco por donde pasaba un riachuelo" se vuelve de actor figurativo antropomorfo en zoomorfo y está condenada a cantar su desdicha ${ }^{41}$, siendo el objeto de valor zapallo el que se esparce "por todas partes, convirtiéndose en el barro con el que ahora las mujeres hacen las ollas"; en la segunda, si también Aúju canta mientras sigue a su marido, es su cuerpo el que al caer se transforma en arcilla. Sea, pues, el zapallo convertido en arcilla sea el cuerpo de Aúju el que sufre el cambio, notemos un hecho común: entre las cosas que lleva y luego caen con ella, están ciertas "ollas" y "objetos de cocina", pero además, en Ib-4 se dice de Aúju que al perseguir a Nántu "como estaba embarazada subía lentamente" y en la nota 3 de Ib-5 se explica que ella "se comió los zapallos maduros porque estaba encinta".

Si interpretamos correctamente este episodio, tendríamos dos tipos de arcilla, una preexistente que permitía y aún permite hacer cierto tipo de vasijas (como las piningas de que se habla en Ib-4) utilizadas en la cocina y otra clase 
de arcilla que sólo existe actualmente y se le encuentra en las orillas de los riachuelos, posibilitando la confección de distintos recipientes. Si se coloca este agregado de una arcilla originada del zapallo o del cuerpo de Auju (B) a la ya preexistente (A) en el eje de la temporalidad eónica - esto es, período de tiempo indefinido e incomputable propio de los mitos--, y si consideramos el otro dato proporcionado por la secuencia registrada en la nota $3 \mathrm{de} \mathrm{Ib}-5$ en referencia a la calidad de la arcilla (categorías figurales paradigmáticas: buena/mala), tenemos:

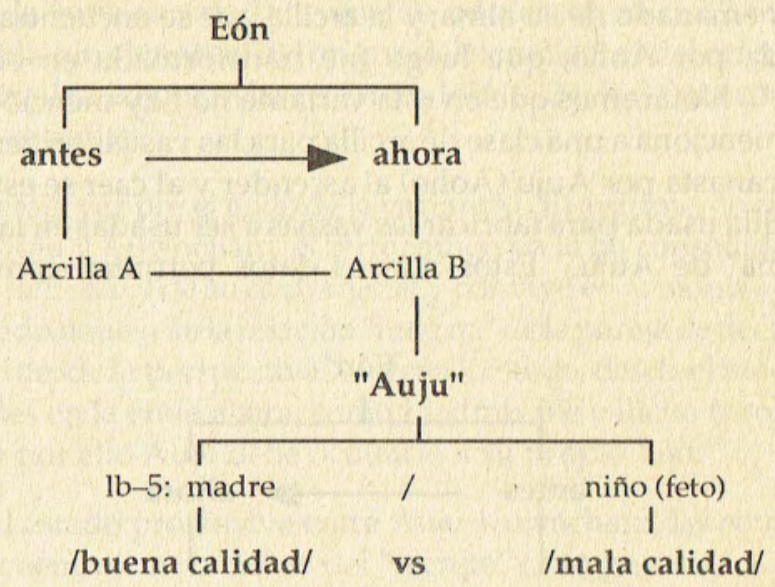

Este diagrama remite, sin dudas, a las secuencia doble, ora de la variante I, ora de la variante Ia-1, que contiene precisamente el motivo de origen de la arcilla. Efectivamente, en la variante I el relato del motivo que tratamos se halla dividido por la inserción del motivo del origen de las manchas de la luna y en la variante Ia-1 la cesura se da por la introducción de parte del motivo del origen de la monogamia. Ahora bien, si aislamos las dos partes de la secuencia textual correspondiente al motivo del origen de la arcilla, notaremos que ellas se distinguen muy poco de la organización canónica que acabo de presentar.

La realización de la sanción final en I se da, otra vez, con el proyecto por parte de Auju de alcanzar a Nantu: "en el canasto, chankín, más grande que tenía, colocó sus cosas, sus ollas, la tablilla de alfarería y la misma arcilla, junto con los comederos de los perros. Cargó con todo a las espaldas y comenzó a trepar el Etsa-Náik para subirse al cielo" y en Ia-1, "llevaba consigo una canasta llena de núi del tipo que utilizan las mujeres jíbaro para hacer sus vasijas de 
barro". Este intento se ve frustrado en I por intervención de Etsa y la ardilla; Auju cae y revienta transformándose "en una lechuza de boca ancha y otras partes de su cuerpo, cayendo en varias partes de la tierra, se transformaron en arcilla de buena o mala calidad" y el demiurgo Etsa le confiere dos tipos de gritos para distinguirlas. Al contrario, en Ia-1 es Luna quien frustra el plan "y la mujer cayó al suelo con la canasta que llevaba. La arcilla se esparció y por donde cayó algo de ella, todavía se encuentra arcilla hoy en día [...] la arcilla, de la cual las mujeres hacen vasijas de barro para las fiestas, tiene su origen en la mujer Aoho, al haber emanado de su alma; y la arcilla que se encuentra hoy en día, ha sido esparcida por Aoho, que luego fue transformada en el pájaro del mismo nombre". Notaremos que en esta variante no hay mención alguna al zapallo; sólo se menciona a una clase de arcilla para las vasijas en general que es portada en una canasta por Auju (Aoho) al ascender y al caer se esparce. Otra distinta es la arcilla usada para fabricar las vasijas a ser usadas en las fiestas: ella emanó del "alma" de Auju. Estos nuevos datos permiten completar el diagrama anterior:

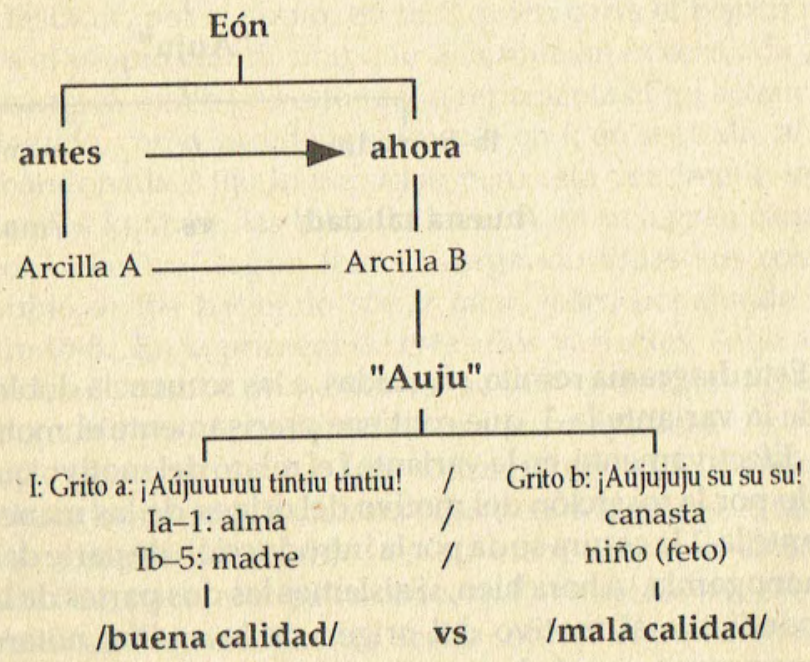

En resumidas cuentas, la figura de la arcilla es actancialmente un objeto de valor que, como en el motivo anterior, la figura del zapallo, puede jugar autorecursivamente (arcilla :: arcilla); pero en el caso de la transformación de un elemento por el otro, a diferencia del zapallo que sólo cumple el rol temático de originador, la arcilla recibe únicamente el rol temático de originada: son, desde este punto de vista, figuras intercambiables en un único sentido. La propiedad 
del "informe" que sería común a ambas, se ve así regida por esta orientación (zapallo $\longrightarrow$ arcilla) que niega su conmutabilidad simple (zapallo :: arcilla) como podría inferirse, cosa que se ha hecho, de la sola afirmación de esa característica semántica compartida.

\subsubsection{Origen de las manchas de la luna}

La variante I presenta la secuencia textual que relata el motivo del origen de las manchas de la luna insertada, como se advirtiera en 3.2.2, entre la secuencia correspondiente al motivo del origen del zapallo y al del origen de la arcilla, variante a la cual se adjuntan las restantes Ic-1, Ic-2 y Ic-3 para constituir el minisub-corpus a estudiar.

Comenzemos esta vez por el texto de la variante I. El argumento empieza con la situación de Auju y Kujáncham, el zorro, quien ya la ha consolado ${ }^{42}$ (rol temático y patémico: aliviador) de su contrariedad y convive en armonía con ella. Sin embargo, ese estado neutro de la relación "interna" de la pareja de deceptores (o "trikster"), es visto desde la perspectiva "externa", esto es, desde el modelo de las relaciones sexuales en la etnia jíbara, como inadmisible e ilícito (prohibido: /deber no hacer/) y por ello Auju debe ocultarlo a su propio hijo.

Retornando al estado protensivo entre Auju-Kujáncham, las competencias de ambos se encuentran en la deíxis del "secreto" (/no parecer/ + /ser/), mientras que la competencia del hijo ocupa la deíxis contraria de la "ilusión" (/no ser/ + /parecer/). De ahí la categoría temática ética y tímica compartida por los deceptores: el escrúpulo ("así pasar juntos los dos sin aprensiones") definido como "duda o recelo que inquieta la conciencia"43. El estado de ánimo inquietud, que se debe esta vez a la "mala conciencia" de los protagonistas, se tensa de tal manera que termina por conmover la competencia de Auju quien, a su vez, adquiere la disposición afectiva de ansiosa y con ello el rol actancial de destinadora-manipuladora ("Un día dijo a Kujáncham: -Trepa el etsa-naik y trae a Nantu, para que salga de caza con su hijo", modalizado por el /hacer hacer/ dirigido a su concubino). La etapa incoativa aparece con el vertimiento en la competencia de Kujáncham, ahora destinatario-manipulado, del rol patémico del deseador, definido como "movimiento del ánimo hacia el disfrute de algo" y modalizado por el / querer poder hacer/, o sea, poseer a Auju. En la fase durativa asciende al cielo donde intentará coger a Nantu: es la prueba calificante exitosa (/saber hacer/) de nuestro relato:

$$
\text { PNU: } \mathrm{F}\left[\mathrm{S}_{0} \longrightarrow(\mathrm{S} \cap \mathrm{O})\right]
$$


PNU: Programa Narrativo de Uso; F: Función transformadora; $\mathrm{S}_{0}$ Sujeto Operador: Kujáncham; S: sujeto de Estado: luna; O: Objeto de Valor: aprensión.

Pero el rol patémico de indignado, definido por el diccionario: "ira, enfado vehemente contra una persona o cosa" se apodera de la competencia de Nantu. De esta manera, ese rol entra a formar parte del campo léxico del descontento que produce el episodio terminativo del relato con la disjunción furibunda ("Nantu indignado contra el concubino de su mujer, en su ardor, le quemó las manos y de un empujón lo tiró a la tierra, en donde se estrelló como un bólido"). El microrelato descrito contiene, entonces, otro Programa que desarrolla la prueba calificante en la dimensión pragmática:

\section{PNB: $F\left[S_{0}(S \cup \mathrm{O}) \rightarrow(\mathrm{S} \cap \mathrm{O})\right]$}

PNU: Programa Narrativo de Base; F: Función transformadora; $\mathrm{S}_{0}$ Sujeto Operador:Kujáncham;S:Sujeto de Estado: Nantu; O:Objeto de Valor: manchas.

Desde el punto de vista de Nantu, durante las etapas incoativa y durativa del relato se halla libre de la categoría figurativa estésica negativa "manchas", está "desmanchado", pero una vez que ocurre la prueba principal adquiere las manchas que señalan su estado perenne ("Hasta ahora podemos ver en la luna esas manchas, que son los dedos chamuscados de Kujáncham, el zorro").

La variante Ic-1 presenta a Auju como el actor figurativo-Anga (sema: /feminidad/) y Nantu bajo la forma del actor figurativo Luna (sema:/ masculinidad/), ambos signados en tanto / humanos/. Como en la variante I, se trata en Ic-1 de un estado neutro y estable entre ellos ("Luna iba de visita a ver a Anga todas las noches y dormía con ella") durante el tiempo mítico primordial o eón del "antes" del presente de la enunciación ("en tiempo antiguos"), pero desde la perspectiva social se trata de una situación prohibida (/deber no hacer/: "era su amante"): de ahí que, en cuanto a la veridicción del relato, Luna es un deceptor pues oculta implícitamentesu identidad ("secreto": / no parecer/+/ser/) mientras Anga permanece en la "ilusión" (/no ser/ +/parecer/). La intriga se inaugura con el desasosiego o estado de ánimo inquieto de Anga originado por su curiosidad ("deseo de saber y averiguar alguna cosa": / quiere saber/ la identidad de Luna). "Para reconocerlo" emplea, en el curso de la etapa incoativa, una prueba calificante modalizada por el /saber hacer/ presupuesto en su competencia ("Anga una noche ennegreció las mejillas de la luna con huituc"), Programa incoativo que en la dimensión pragmática conduce hacia la prueba decisiva: 


\section{PNU: $\mathrm{F}\left[\mathrm{S}_{0} \longrightarrow(\mathrm{S} \cap \mathrm{O})\right]$}

PNU: Programa Narrativo de Uso; F: Función transformadora; $S_{0}$ : Sujeto Operador: Anga; S: Sujeto de Estado: luna; O: Objeto de Valor: manchas.

La prueba decisiva se da, como en el caso anterior, en la etapa durativa del relato ("Luna trató de limpiarse las manchas negras de las mejillas") y decide, siempre en la dimensión pragmática, el Programa principal fracasado:

\section{PNB: $F\left[S_{\mathrm{O}}(\mathrm{S} \cup \mathrm{O}) \rightarrow(\mathrm{S} \cap \mathrm{O})\right]$}

PNB: Programa Narrativo de Base; F: Función transformadora; $\mathrm{S}_{0}$ : Sujeto Operador: Anga; S: Sujeto de Estado: luna; O: Objeto de Valor: manchas.

Así, Luna no pudo desmancharse ("Inclusive hoy en día las manchas negras son visibles en la cara de la luna, como todos pueden ver") e incorpora en su competencia el rol patémico del avergonzado (/no querer haber hecho/) que se agrega a los anteriores lexemas en el campo léxico del descontento; todo ello lo impele a dejar "la tierra y la mujer para siempre, trepando al cielo por un gran bejuco". Este último episodio y la sanción de la derrelicción de Anga está desde luego en la variante I pero, como sabemos, precediendo al actual motivo del origen de las manchas de la luna: es el episodio terminativo del motivo del origen de la monogamia y esa variante, al incluir los dos motivos, por la ley de no redundancia en la economía narrativa, ahorra la repetición de dicho episodio para el motivo del origen de las manchas de la luna.

Pasemos a la variante Ic-2. En ella encontramos una situación similar a la narrada en las variantes anteriores dentro de la época primordial ("Antiguamente") en que la luna era ser humano (sema:/masculino/); no obstante, en Ic-2 se le concibe como formando parte de una familia extensa. Ahora bien, a la inversa de I es su mujer (Auju) y su hermana quien "lo aceptaba pero no sabía. quién era", las que ostentan los roles temáticos de consortes de Nantu. Semejante estado inicial es neutro y los actantes protensivos, pero se mantiene una tensividad fórica en el ánimo de la hermana que "aunque intentaba agarrarlo fuertemente para descubrirlo cuando amaneciera, Nantu siempre lograba escapar y volver a su cama antes de que se viese nada". En consecuencia, la competencia de Nantu como deceptor ocupa la categoría modal veridictoria del "secreto" (/no parecer/+/ser/) y la hermana la de la "ilusión" (/no ser/+ /parecer/). La inquietud, que se debe esta vez también al rol patémico de la 
curiosidad (/querer saber/) en la competencia de la hermana, se tensa ("Una noche, Nántu volvió a la cama de su ubán; aunque đormía, notó que alguien intentaba forzarla. La mujer quiso agarrar al hombre pero, nuevamente, Nantu consiguió escapar"; / no poder saber/) y termina por decidirla a pedir consejo a su madre.

La prueba calificante la efectúa la madre quien, como adyuvante de la hermana y sujeto operador a la vez, le transmite el /saber hacer/ que necesita para satisfacer su curiosidad. Tal es la etapa incoativa de esta variante cuyo Programa permite a la hermana adquirir la competencia suficiente para realizar la prueba principal:

$$
\text { PNU: } \mathrm{F}\left[\mathrm{S}_{0} \longrightarrow(\mathrm{S} \cap \mathrm{O})\right]
$$

PNU: Programa Narrativo de Uso; F: Función transformadora; $\mathrm{S}_{0}$ : Sujeto Operador: madre; S: Sujeto de Estado: hermana; O: Objeto Modal: /saber hacer/.

La etapa durativa muestra a la hermana ocupada en la preparación de la pintura y dejarla lista para efectuar la prueba decisiva que ocurrirá esa misma noche. Ella pinta la cara de Nantu quien se retira de inmediato. La fase terminativa comienza al día siguiente cuando los familiares, al notar la pintura en su rostro, descubren el "secreto" que guardaba; es entonces acusado por la hermana y reprendido por la familia, pasando así a la categoría veridictoria de la "verdad": ha sido descubierto (/ser/t/parecer/). Este episodio permite completar la estructura elemental de la significación que resume y sistematiza el modelo social de las relaciones sexuale ${ }^{44}$ propias de la etnia jíbara, estructura que se ha ido perfilando en las variantes anteriores (I, Ia-1, Ia-4, Ib-2 y Ic-1):

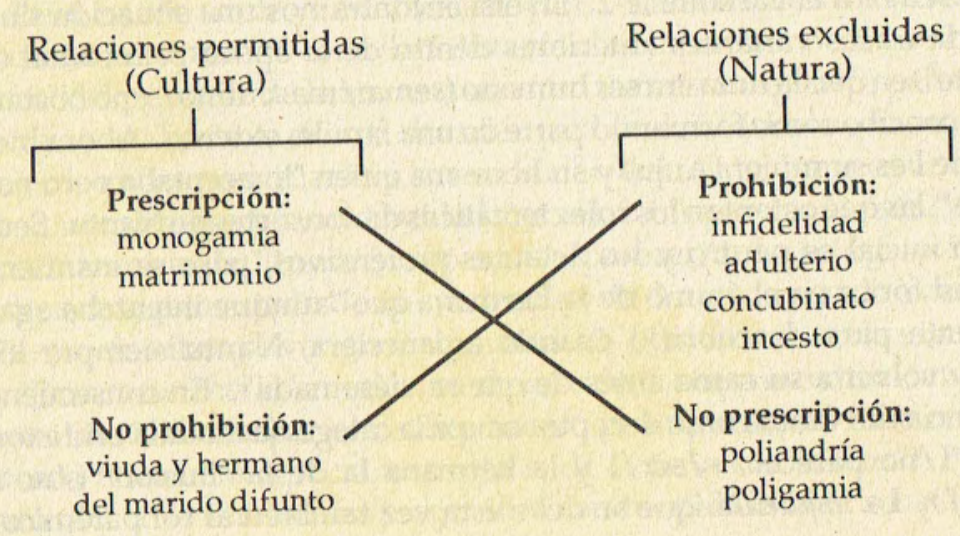


Nántu desempeña ahora en Ic-2 el rol patémico del avergonzado, similar al de la variante precedente. Y ello lo lleva a buscar un adyuvante que cumpla con él el mismo papel de la madre de ambos en relación a la hermana: este antiadyuvante buscado es su mujer, Auju, quien se halla espacialmente disjunta del grupo. Pero al encontrarla (conjunción) y solicitarle un "chapo de zapallo" (Objetivo de Valor), ella se lo niega, rechazando en su competencia -por presuposición-el rol de aliada de Nántu, de aceptación de su condición de incestuoso; tal es la prueba principal o decisiva fracasada, pues queda condenado a permanecer manchado:

\section{PNB: $\mathrm{F}\left[\mathrm{S}_{0}(\mathrm{~S} \cup \mathrm{O}) \rightarrow(\mathrm{S} \cap \mathrm{O})\right]$}

PNB: Programa Narrativo de Base; F: Función transformadora; $\mathrm{S}_{0}$ :Sujeto Operador: Auju; S: Sujeto de Estado: Nántu; O: Objeto de Valor: manchas.

En la fase terminativa, el estado de ánimo vergonzoso que ahora ha sido acentuado con la del rol patémico de triste ("sentimiento de aflicción, pesadumbre o melancolía") -lexema a incluir en el campo léxico del descontento-, sube al cielo llevando consigo a su hija ${ }^{45}$ y ostenta la sanción recibida: "Nántu todavía tiene su cara manchada de negro, desde que su ubán se la pintó con suwá".

Finalmente, en la variante Ic-3 volvemos a encontrar al personaje Kujáncham (zorro/zarigüeya) que ya intervino en I. El relato notable por su disforia leve (sólo encontramos un rol patémico), contiene sin embargo numerosos enunciados que manifiestan la enunciación entre el enunciador-informante y el enunciatario-receptor (o enunciación enunciada: "Mi apán así me contó y él no puede hablar de lo que no conoce", "¿No ves...?", "¿No te has fijado...?", "Fíjate bien después, pensando en esto", "¿Por qué no habrá pensado bien?", etc.), enunciados que deben ser descartados por no ser pertinentes para la descripción y explicación del motivo. Esta variante pone en escena a Nántu quien, caído del cielo, continúa alumbrando en la tierra. Se trata pues de la etapa $a b$ initio que desarrolla en forma concisa la prueba calificante propia de esta serie, pero donde el "destino" es un actante presupuesto:

$$
\mathrm{PNU}_{1}: \mathrm{F}\left[\mathrm{S}_{0} \rightarrow(\mathrm{S} \cap \mathrm{O})\right]
$$

$\mathrm{PNU}_{1}$ : Programa Narrativo de Uso 1; F: Función transformadora; $\mathrm{S}_{0}$ :Sujeto Operador: destino; S: Sujeto de Estado: Nántu; O: Objeto de Valor: alumbrar. 
El episodio media ad finen es aquí igualmente muy condensado y se manifiesta con el proyecto de Kujáncham de llevar a Nántu para que su hijo lo vea. Al contrario, la etapa ad finem se da mucho más expandida y comprende:

a) la captura de Nántu por Kujáncham;

b) en el plano pragmático Nántu, además de alumbrar, calienta "como Sol, Etsa";

c) la mano de Kujáncham deja su huella en Nántu, quien queda marcado;

d) a la vez, la facultad de calentar de Nántu pasa a la mano (¿pata?) de Kujáncham.

Todo este conjunto de acciones reitera, en primer lugar, el Programa principal del motivo y su correspondiente prueba decisiva; pero como esta prueba afecta también a Kujáncham, la fórmula será leída de dos maneras:

$$
\text { PNB: } F\left[\mathrm{~S}_{0}(\mathrm{~S} \cup \mathrm{O}) \longrightarrow(\mathrm{S} \cap \mathrm{O})\right]
$$

a) PNB: Programa Narrativo de Base; F: Función transformadora; $\mathrm{S}_{0}$ : Sujeto Operador: Kujáncham; S: Sujeto de Estado: Nántu; O: Objeto de Valor: marcas;

b) PNB: Programa Narrativo de Base; F: Función transformadora; $\mathrm{S}_{0}$ : Sujeto Operador: Nantu; S: Sujeto de Estado: Kujáncham; O: Objeto de Valor: calor.

Semejante duplicación se debe a que en la variante Ic-3 hay un traslapamiento sobre la sanción canónica del PNB del motivo del origen de las manchas de la luna, un nuevo PNU cuyo fin es precisamente desencadenar un PNB que anule la segunda lectura de esta PNB que acabo de formular. Veamos cómo se produce esta instancia reordenadora.

Kujáncham adquiere de Nántu, decía, la facultad de calentar y con ello de "secar la ropa". Tal es el estado original que presenta la etapa incoativa del relato traslapado y la respectiva prueba calificante:

$$
\mathrm{PNU}_{2}: \mathrm{F}\left[\mathrm{S}_{0} \rightarrow(\mathrm{S} \cap \mathrm{O})\right]
$$

$\mathrm{PNU}_{2}$ : Programa Narrativo de Uso 2; F: Función transformadora; $\mathrm{S}_{0}$ : Sujeto Operador:Nántu;S:Sujetọ de Estado: Kujáncham;O:Objeto de Valor:alumbrar / calentar. 
La fase durativa procede a partir de la orden (/debe hacer/) que recibe Kujáncham como destinatario de un destinador desconocido: "dijeron", "le mandaron" (?). El realiza el trabajo que se le ha impuesto (constatar si han caído palomas en las trampas colocadas por el destinador), pero duda de la efectividad de las trampas, adquiriendo el rol temático y patémico de desconfiado ("no confiar, sentir recelo o desesperanza": "-iAcaso con esta clase de trampas puede caer el yámpits!": / no creer / en los demás) que, desde luego, ocupa su lugar en el campo léxico del descontento. En seguida decide efectuar la prueba decisiva, probar la trampa; como aparece en el texto, él queda finalmente colgado por su pene de la trampa en lo alto. He aquí, pues, en la fase terminativa, la posición contrapuesta a la de Nántu caído del cielo, es decir, la estructura espacial invertida que comienza a reestablecer la organización original. Por último, Kujáncham logra deshacerse de la trampa y retornar al lugar donde partió, pero para entonces, aunque revivirá al desatar su pene, va perdiendo las capacidades de alumbrar ("alumbraba cada vez menos", "alumbraba amarillo") -semejante a la luna en relación al sol, como se ha visto en las variantes precedentes-y de calentar ("enfriándose, enfriándose"). De ahí la sanción que no es otra que la anulación de la segunda lectura del PNB; a la adquisición del calor vista en b), le sucede ahora su pérdida y la adquisición definitiva del frío ("Porque sucedió así, - ahora el kujáncham tiene la mano fría, dicen") por obra de ese actante innominado que es el "destino":

\section{PNB: $\mathrm{F}\left[\mathrm{S}_{0}(\mathrm{~S} \cup \mathrm{O}) \longrightarrow(\mathrm{S} \cap \mathrm{O})\right]$}

PNB: Programa Narrativo de Base; F: Función transformadora; $\mathrm{S}_{0}$ : Sujeto Operador: destino; S: Sujeto de Estado: Kujáncham; O: Objeto de valor: frío.

Las categorías figurales paradigmáticas calor / frío que abren la intriga del motivo etiológico de la monogamia, cierran ahora el motivo del origen de las manchas de la luna confirmando, una vez más, la coherencia general del corpus elegido.

\section{OBSERVACIONES PARA CONTINUAR}

En el estudio de Claude Lévi-Strauss que me he permitido glosar más arriba, se reúne especialmente una categoría figurativa, la arcilla y una figura actorial, la alfarera, con una categoría tímica, los celos. La generalización de ese 
esquema el cual, en cierto modo, haría de la arcilla y la alfarera los "símbolos" de los celos, orienta el derrotero del examen antropológico. El enfoque seguido aquí, pone más bien el acento en la organización semántica particular de las variantes producidas por la etnia jíbara, a partir de la idea según la cual, si bien el aspecto sintáctico del relato revela una invariancia susceptible de generalizarse, su armazón semántica varía según el área cultural espacial y temporalmente considerada. En resumidas cuentas, los celos ¿simbolizan efectivamente el origen de la arcilla y del arte de las alfareras en las sociedades ancestrales? El estudio del componente semántico de las variantes analizadas, con énfasis en la descripción de las configuraciones anímicas (o universo pasional), no parece confirmar una respuesta aseverativa para el motivo sobre el origen de la arcilla.

El examen puesto en práctica por el enfoque semiolingüístico para demostrarlo, ha sido el de atenerse estrictamente al universo de referencia dispuesto por las variantes tomadas de la etnia jibara, destacando en alto relieve las funciones relaciones "semi-simbólicas" paradigmáticas, es decir, aquellas que congregan de manera codificada las categorías figurales manifestadas por dichas variantes (arriba /abajo, antes / después, buena / mala, par/dispar, etc.), y sintagmáticas, de naturaleza figurativa isotopante (zapallo / arcilla, huituc/ manchas, etc.), así como las categorías figurativas estésicas ("buenos mozos", "plenilunio", "más hermoso que nunca", "manchas"); en cuanto al plano temático $^{46}$, se ha correlacionado las categorías temáticas genéricas (por ejemplo, la oposición modal /no saber/vs /saber/) y las temáticas específicas (por ejemplo, indiferencia / percatarse) o las categorías temáticas éticas (por ejemplo, acaparar/ despojar, buen comportamiento / mal comportamiento, perplejidad / decepción, escrúpulos); finalmente, en el plano axiológico reglado por las categorías tímicas de la foria (euforia / disforia) -que, desde luego, pueden subsumir cualquier figura o tema-, las oposiciones categoriales (por ejemplo, atracción / repulsión) y principalmente la descripción de los estados de ánimo (burla / celos, resentimiento / enojo, acompañamiento / derrelicción, abulia / diligencia, etc.).

Ello ha permitido constatar, luego del confrontamiento analítico, cómo cada motivo ahorma de manera especial e independiente sus diversas instancias figurativas, temáticas y axiológicas, no obstante encontrarse combinado con otros motivos en el texto de una misma variante. Así, los celos no son un estado de ánimo que interviene en el motivo del origen de la arcilla; lo encontramos especialmente como el estado pasional que provoca el origen de la monogamia y participa en el motivo del origen del zapallo. Es decir que su relación con la categoría figurativa abstracta "monogamia" y con la categoría 
figurativa icónica "zapallo" que dan título a los respectivos motivos, demuestra bien su carácter semi-simbólico; si se quisiera encontrar un estado de ánimo que simbolizara, en la cultura jíbara, el origen de la arcilla sería, preferentemente y en el mejor de los casos, el de la categoría temática específica y tímica de la avidez -como Lévi-Strauss lo insinúa, aunque sólo dentro de su sistema tripartito visto en $2^{47}$-, pero incluso esa categoría informa directamente el motivo etiológico del zapallo. Todo esto me lleva a pensar que es muy hipotético establecer una relación simbólica estricta entre una categoría axiológica, por ejemplo, el estado de ánimo celos, y una figura icónica, por ejemplo, la arcilla. Queda por averiguar la naturaleza de esa ilación en un sub-corpus compuesto por variantes que contengan el motivo del origen de la alfarería; en la segunda parte de este artículo, se estudiará lo atinente a la etiología de ese oficio en la cultura y civilización jíbaras.

\section{NOTAS}

1. cf. Ballón Aguirre, E., 1987a.

2. En el Perú tenemos una preciosa muestra de la larga duración etnoliteraria con los relatos orales transcritos y conservados en el manuscrito de Huarochirí (cf. Taylor, G., 1987) y las variantes recogidas en el mismo lugar cuatro siglos después (cf. Ortiz Rescaniere, A., 1980).

3. Recuérdese que según T.S. Eliot, no existen poemas terminados, sólo abandona dos.

4. Lévi-Strauss, C., 1984: 109-111.

5. Denominados en El hombre desnudo, volumen IV de sus Mitológicas, zoemas: especies animales provistas de una función semántica, que permiten mantener constante la forma de sus operaciones en vastosterritorios, a pesar de que difieran la geología, el clima, la fauna y la flora. Se trata, entonces, de figuras zoológicas unidas a temas fijos.

6. Lévi-Strauss, Claude, 1986: 113 y 119.

7. Título original:La potiére jalouse. París: Plon, 315 pp.; versión española, La alfarera celosa. Barcelona: Paidós, 1986, 213 pp. Para facilitar su consulta en adelante se citará por la versión castellana.

8. C. Calame, 1990: 12 n. 9, ha observado este procedimiento.

9. He aquí uno de los planteamiento que todas esas disciplinas pueden compartir: "Los mitos, y quizá también los sueños, establecen una pluralidad de símbolos que, tomados por separado, no significan nada. Sólo adquieren un significado en la medida en que establecen relaciones entre ellos. Su significado no existe en to absoluto; es única "de posición", Lévi-Strauss, C., 1986: 176. 
10. cf. Jakobson, R. y Bogatyrev, P., 1973.

11. cf. Ballón Aguirre, E., 1987b.

12. cf. Rey, A., 1970:283.

13. cf. Rastier, F., 1987:49, n. 17.

14. cf. Ballón Aguirre, E., Cerrón-Palomino, R. y Chambi Apaza, E., 1992: 45.

15. Lévi-Strauss, C., 1986:127.

16. Lévi-Strauss, C., 1976:16. Glosando este concepto, M. Coquet, 1991:1, escribe: "El mito es una "matriz de inteligibilidad" que permite dar un sentido al mundo y que todo miembro de una misma sociedad a integrado como dato fundamental de su cultura, como garantía misma de su especifidad cultural: en las culturas de mitos, todo eso que es producto es integrado a esta matriz, la lengua, el arte, los códigos jurídicos, las instituciones sociales, las religiones, las técnicas, etc."

17. cf. Lévi-Strauss, c., 1976, cap. I. Se han incluido los textos completos de las variantes obtenidas por R. Karsten, J. M. Guallart y S. Pellizzaro, a los cuales se han agregado otros con el fin de completar el corpus de estudio.

18. Esta información ha sido obtenida de L. M. Uriarte, 1976 y de R. Ravines y R. Avalos de Matos, 1988. En este último Atlas se indica que los grupos Huambisa y Shuar son independientes y que sólo hay un grupo Candoshi (Shapra, Chapra, Murato), no incluyéndose en ningún grupo a los Wampís del río Santiago (Kanús).

19. La relación ha sido consignada por F. Barriga López, 1986; para P.y A. Costales, 1983: 102, el territorio ocupado por la familia lingüística jíbara es: Pastaza, Corrientes y Tigre al Norte; Chinchipe al Sur y Alto Amazonas al Sureste, con lo cual "el habitat de los jíbaros (6 grupos etnolingüísticos [sin contar a los Jívaros propiamente dichos]) en ubicaciones geográficas distintas, es el más vasto complejo demogeográfico de la amazonía del Ecuador y del Perú". El Atlas Etnolingüístico del Perú coincide con esta apreciación sobre el territorio ocupado por la familia Jíbaro/Shuar (cf. mapa de la p. 46).

20. cf. Ballón Aguirre, E., Cerrón-Palomino, R. y Chambi Apaza, E., 1992:22-24.

21. Nohe tenidoen cuenta las variantes-resúmenes cuandoéstas son obra únicamente del recopilador y no grabadas por la informantes, transcritas, traducidas e interpretadas con su ayuda; por ejemplo, Pellizzaro, Siro M., Leyendas Shuaras. Cuenca: Editorial "Don Bosco", s.f.y Farabee, William Curtis, Indian tribes of Eastern Perú, X. Cambridge(Massachusetts): Peabody Museum of American Archaelogy and Ethnology, Harvard University, 1922, 124-125. A las resemantizaciones ya sufridas por la traducción, se les suma en esos textos las condensaciones que, de hecho, acarrean supresiones descontroladas. Para la organización interna del conjunto de variantes considerado como corpus y su análisis, sigo esta regla metodológica: "cuando se cuenta con diversas variantes de un mismo texto, hay que tomar como texto de referencia el que presente el hecho que se analiza de la 
manera más explícita posible", Greimas, A. J., 1985:117.

cf. Greimas, A. J. y Courtés, J., 1982:77.

23. Ibid. p. 404.

"Catástrofe", en el sentido matemático y semiótico del término, Ibid., pp. 40-42. Greimas, A. J. y Fontanille, J., 1991:26, escriben: "el sujeto como sujeto de estado sólo puede ser modalmente afectado por medio del vertimiento del objeto cuya carga modal, a condición que se le plantee en relación de junción con el sujeto, modaliza a su vez este último. En otras palabras, la modalización del estado del sujeto -y es de eso que se trata cuando se quiere hablar de las pasiones- sólo es concebible pasando por la del objeto que, convirtiéndoseen un "valor", seimpone al sujeto".

27. cf. Greimas, A. J., 1989:255 y sig.

28. C. Rubina, 1992:74 y sig., estudia los alcances en la etnoliteratura andina de la petrificación como metamorfosis, fenómeno narrativo que por lo visto tiene estrechas relaciones con nuestro caso.

29. /Querer/ y /desear/ pertenecen al mismo universo cognoscitivo o conjunto modal halotáctico (cf. Greimas A. J. y Courtés J., 1991:133).

30. cf. Greimas, A. J. y Fontanille, J., 1991:41.

31. cf. Ballón Aguirre, E., 1991.

32. cf. Greimas, A. J. y Courtés J., 1991:199.

33. Esta variante incluye una mención simple del zapallo perteneciente al motivo del origen de la arcilla que veremos más adelante.

34. cf. Greimas, A. J. y Fontanille, J., 1991:52-53.

35. Para la noción de contexto, cf. Ballón Aguirre, E., 1992:121 y sig.

36. La pieza de Esquilo Prometeo encadenado es, desde esta perspectiva, una variante más del motivo correspondiente incluido por Hesiodo, 1986:70-71.

37. La modalidad del / querer/ se manifiesta en el sintagma "con todo el deseo de su ser"; ahora bien, recordemos que "querer" y "desear" no son sólo términos parasinónimos sino que constituyen modalidades halotácticas entre sí (cf. nota 29).

38. Greimas, A. J., 1989:263 y sig.

39. Recuérdese que el estado de ánimo cólera queda siempre suspendido en la configuración del origen de la monogamia.

40. En la lengua española, el pájaro chotacabras tiene un parasinónimo: "Engañapastores"; cf. Greimas, A. J. y Courtés J., 1982:102-103.

41. Fuera del hecho de que Auju "roba" a la luna en Ib-3y Ib-4 el zapallo que originará la arcilla, el paso del plano celeste al terrestre y el abandono y soledad a que se ve condenada, todas las similitudes con el mito de Prometeo, las variantes Ib-3, Ib4 y lb-5 integran la secuencia del lamento de Auju, análoga a la secuencia que 
cuenta la condena de Prometeo y sus lamentos al sentir roidas sus entrañas por un pájaro (buitre).

42. En la variante del mito de Prometeo atribuida a Esquilo, la semidiosa lo consuela en su desgracia.

43. "Recelar" admite, además, los parasinónimos: "temer", "desconfiar" y "sospechar".

44. cf. Greimas, A. J., 1970:135 y sig.

45. cf. nota 42 .

46. cf. Courtés, J., 1991:171 y sig.

47. C. Lévi-Strauss, 1986:73, relaciona expresamente "avidez oral y retención anal: el par chotacabras-perezoso". En el mismo lugar, Lévi-Strauss indica que "plantear la avidez oral como una categoría del pensamiento mítico invita a preguntarse si esta categoría existe en y por sí misma, si por sí sola forma un todo, o si, al separarla de los materiales sometidos al análisis, no se ha aislado una parcela de un campo semántico, un estado entre otros de una transformación", concluyendo que en su cuadro de conmutaciones "la avidez oral ocuparía sólo una casilla"; esa casilla a parece en el vértice del triángulo diagramado en 2 . Además, el lexema "avidez" como "deseo inmoderado" da lugar a una descomposición léxica en las locuciones o expresiones estereotipadas "ávido de ternura", "ávido de saber", "ávido de placeres", etc., locual hace de ese lexema una categoría temática y tímica poco adecuada para los fines indicados (sobre la pasión de la avidez y su definición léxico semántica, cf. Greimas, A.J. y Fontanille, J., 1991: 118-120, 138, $165,166)$.

\section{BIBLIOGRAFIA}

BALLÓN AGUIRRE, ENRIQUE,

1987a "Historiografía de la literatura en sociedades plurinacionales(multilingües y pluriculturales)", Filología, XXII, 2, Buenos Aires: Universidad de Buenos Aires, Facultad de Filosofía y Letras, Instituto de Filología y Literaturas Hispánicas "Dr. Amado Alonso", 5-25.

1987b "Una escrucijada entre filología, lingüística y semiótica: el corpus", Dispositivo-Revista Hispánica de Semiótica Literaria, XII, 30-32, Ann Arbor: University of Michigan, Department of Romance Languages 65-82. 
1991 "Etnoliteratura andina: El motivo Desafío". Antropológica, 9. Lima: Departamento de Ciencias Sociales de la Pontificia Universidad Católica del Perú, 75-96.

1992 "Etnoliteratura y literatura oral peruanas", Mester, XXI, 2. Los Angeles: University of California, Departament of Spanish and Portuguese, Fall 1992, 109-131.

BALLÓN AGUIRRE, ENRIQUE, CERRÓN-PALOMINO, RODOLFO Y CHAMBI APAZA, EMILIO,

1992 Vocabulario razonado de la actividad agraria andina. Cuzco: Centro de Estudios Regionales Andinos "Bartolomé de las Casas".

BALLÓN AGUIRRE, ENRIQUE Y GARCÍA RENDUELES, MANUEL.

1978 "Nunkui y la instauración del orden social civilizado", Amazonía Peruana, II, 3. Lima: Centro Amazónico de Antropología y Aplicación Práctica, 99-158.

BARRIGA LÓPEZ, FRANKLIN.

1986. Etnología Ecuatoriana II - Shuaras. Quito: Instituto Ecuatoriano de Crédito Educativo y Becas.

BARRUECO, DOMINGO.

1985 Mitos y leyendas shuar. Quito. Ediciones ABYA-YALA.

CALAME, CLAUDE.

1991 Illusions de la mythologie. Nouveaux Actes Sémiotiques, 12. Limoges: PULIM, Université de Limoges.

COQUET, MICHÉLE,

1991 "Avant-propos". Claude Calame, Illusions de la mythologie, Nouveakux Actes Sémiotiques, 12. Limoges: PULIM, Université de Limoges, 1-4.

COSTALES, PIEDAD Y ALFREDO.

1983 Amazonía Ecuador-Perú-Bolivia. Quito: Mundo Shuar.

COURTÉS, JOSEPH.

1991 Analyse sémiotique du discours - De I'énoncé 'a I'énonciation, París: Hachette. 
CHUMAP LUCIA, AURELIO Y GARCÍA RENDUELES, MANUEL

1979 "Duik múun..."--Universo mítico de los aguarunas. Vol. I. Lima:Centro Amazónico de Antropología y Aplicación Práctica.

GREIMAS, ALGIRDAS J.

1970 Du Sens, París: Seuil.

1985 Des dieux et des hommes, París: Presses Universitaires de France.

1989 Del Sentido II- Ensayos semióticos. Madrid: Gredos.

GREIMAS, ALGIRDAS J. COURTÉS, J.

1982 Semiótica-Diccionario razonado de la teoría del lenguaje. Madrid: Gredos.

1991 Semiótica-Diccionario razonado de la teoría del lenguaje II. Madrid: Gredos.

GREIMAS, ALGIRDAS J. Y FONTANILLE, JACQUES.

1991 Sémiotique des passions - Des états des choses aux états d'âme. París: Seuil.

GUALLART S. J., JOSÉ MARÍA.

1958 "Mitos y leyendas de los aguarunas del Alto Marañón", Perú Indígena Organo del Instituto Indigenista Peruano, VII, 16-17. Lima: julio-diciembre, 59-98.

HESIODO

1986 Teogonía, Trabajos y Días, Escudo, Certamen. Madrid: Alianza Editorial.

JAKOBSON, ROMAN Y BOGATYREV PETR

1973 "Le folklore, forme spécifique de création", en R. Jakobson, Questions de poétique. París: Seuil, 59-72.

JORDANA LAGUNA, JOSÉ LUIS.

1974 Mitos e historias aguarunas. Lima: Retablo de Papel, Ediciones.

KARSTEN, RAFAEL

1989 The Head Hunters of Western Amazonas - The Life and Culture of the jibaro 
Indians of Eastern Ecuador and Perú. Helsigfors: Societas Scientiarum Fennica, Commentationes Humanarum Litterarum, VII. 1, 1935; traducción castellana, La vida y la cultura de los Shuar, Tomos I y II. Guayaquil: Banco Central del Ecuador - Ediciones ABYA-YALA, 1989.

LÉVI-STRAUSS, CLAUDE

1976 "Preface" a Roman Jakobson, Six leçons sur le son et le sens. París: Minuit, 1976.

1984 Paroles doennées. París: Plon.

1986 La alfarera celosa. Barcelona: Paidós, 1986.

1991 Enrique Magaña, "Entrevista a Claude Lévi-Strauss", Anthropológica IX, 9. Lima: Departamento de Ciencias Sociales, P.U.C. 277-285.

ORTIZ RESCANIERE, ALEJANDRO,

1980 Huarochirí, 400 años después. Lima: Pontificia Universidad Católica del Perú.

PELLIZZARO, SIRO.

1990 Arutam-Mitología Shuar. Quito: Ediciones ABYA-YALA.

RASTIER, FRANÇOIS

1987 Sémantique intérpretative. París. Presses Universitaires de France.

RAVINES, ROGGER Y AVALOS DE MATOS, ROSALÍA.

1988 Atlas etnolingüístico del Perú, Lima: Instituto Andino de Artes Populares del Convenio Andrés Bello - Comisión Nacional del Perú.

REY, ALAIN.

1970 "Typologie génetique des dictionnaires", Langages, 19. París: Larousse, 48-68.

RUBINA, CELIA.

1992 "La petrificación en el Manuscrito de Huarochirí", Mester, XXI, 2. Los Angeles: University of California, Department of Spanish and Portuguese, Fall 1992, 71-82. 
Amazonía Peruana

RUEDA, MARCO VINICIO.

1983 Setenta "Mitos Shuar". Quito: Mundo Shuar, 1983.

TAYLOR, GERALD.

1987 Ritos y tradiciones de Huarochirí [¿1608?]. Lima: Instituto de Estudios Peruanos-Instituto Francés de Estudios Andinos.

URIARTE, LUIS M.

1976 "Poblaciones nativas de la Amazonía Peruana", Amazonía Peruana, I, 1. Lima: Centro Amazónico de Antropología y Aplicación Práctica, 9-58. 